\title{
An evaluation of global organic aerosol schemes using airborne observations
}

\author{
Sidhant J. Pai ${ }^{1}$, Colette L. Heald ${ }^{1,2}$, Jeffrey R. Pierce ${ }^{3}$, Salvatore C. Farina ${ }^{3}$, Eloise A. Marais ${ }^{4}$, Jose L. Jimenez ${ }^{5}$, \\ Pedro Campuzano-Jost ${ }^{5}$, Benjamin A. Nault ${ }^{5}$, Ann M. Middlebrook ${ }^{6}$, Hugh Coe ${ }^{7}$, John E. Shilling ${ }^{8}$, Roya Bahreini ${ }^{9}$, \\ Justin H. Dingle ${ }^{9}$, and Kennedy $\mathrm{Vu}^{9}$ \\ ${ }^{1}$ Department of Civil and Environmental Engineering, Massachusetts Institute of Technology, \\ Cambridge, MA 02139, USA \\ ${ }^{2}$ Department of Earth, Atmospheric and Planetary Sciences, Massachusetts Institute of Technology, \\ Cambridge, MA 02139, USA \\ ${ }^{3}$ Department of Atmospheric Science, Colorado State University, Fort Collins, CO 80523, USA \\ ${ }^{4}$ Department of Physics and Astronomy, University of Leicester, Leicester, LE1 7RH, UK \\ ${ }^{5}$ Department of Chemistry, and Cooperative Institute for Research in Environmental Sciences (CIRES), \\ University of Colorado, Boulder, CO 80309, USA \\ ${ }^{6}$ NOAA Earth System Research Laboratory (ESRL) Chemical Sciences Division, 325 Broadway, Boulder, CO 80305, USA \\ ${ }^{7}$ Centre for Atmospheric Science, School of Earth and Environmental Science, \\ University of Manchester, Manchester, M13 9PL, UK \\ ${ }^{8}$ Atmospheric Sciences and Global Change Division, Pacific Northwest National Laboratory, Richland, Washington, USA \\ ${ }^{9}$ Department of Environmental Sciences, University of California, Riverside, CA 92521, USA
}

Correspondence: Sidhant J. Pai (sidhantp@mit.edu) and Colette L. Heald (heald@mit.edu)

Received: 5 April 2019 - Discussion started: 6 May 2019

Revised: 5 December 2019 - Accepted: 3 January 2020 - Published: 4 March 2020

\begin{abstract}
Chemical transport models have historically struggled to accurately simulate the magnitude and variability of observed organic aerosol (OA), with previous studies demonstrating that models significantly underestimate observed concentrations in the troposphere. In this study, we explore two different model OA schemes within the standard GEOS-Chem chemical transport model and evaluate the simulations against a suite of 15 globally distributed airborne campaigns from 2008 to 2017, primarily in the spring and summer seasons. These include the ATom, KORUS-AQ, GoAmazon, FRAPPE, SEAC4RS, SENEX, DC3, CalNex, OP3, EUCAARI, ARCTAS and ARCPAC campaigns and provide broad coverage over a diverse set of atmospheric composition regimes - anthropogenic, biogenic, pyrogenic and remote. The schemes include significant differences in their treatment of the primary and secondary components of OA - a "simple scheme" that models primary OA (POA) as non-volatile and takes a fixed-yield approach to secondary OA (SOA) formation and a "complex scheme" that simulates
\end{abstract}

POA as semi-volatile and uses a more sophisticated volatility basis set approach for non-isoprene SOA, with an explicit aqueous uptake mechanism to model isoprene SOA. Despite these substantial differences, both the simple and complex schemes perform comparably across the aggregate dataset in their ability to capture the observed variability (with an $R^{2}$ of 0.41 and 0.44 , respectively). The simple scheme displays greater skill in minimizing the overall model bias (with a normalized mean bias of 0.04 compared to 0.30 for the complex scheme). Across both schemes, the model skill in reproducing observed OA is superior to previous model evaluations and approaches the fidelity of the sulfate simulation within the GEOS-Chem model. However, there are significant differences in model performance across different chemical source regimes, classified here into seven categories. Higher-resolution nested regional simulations indicate that model resolution is an important factor in capturing variability in highly localized campaigns, while also demonstrating the importance of well-constrained emissions inventories and 
local meteorology, particularly over Asia. Our analysis suggests that a semi-volatile treatment of POA is superior to a non-volatile treatment. It is also likely that the complex scheme parameterization overestimates biogenic SOA at the global scale. While this study identifies factors within the SOA schemes that likely contribute to OA model bias (such as a strong dependency of the bias in the complex scheme on relative humidity and sulfate concentrations), comparisons with the skill of the sulfate aerosol scheme in GEOS-Chem indicate the importance of other drivers of bias, such as emissions, transport and deposition, that are exogenous to the OA chemical scheme.

\section{Introduction}

Aerosols in the atmosphere have significant climate impacts through radiative scattering and cloud formation (IPCC, 2013; Ramanathan et al., 2001). Exposure to these particles is also detrimental to human health and is associated with over 4 million premature deaths per year worldwide (Pope and Dockery, 2006; Cohen et al., 2017). Organic aerosol (OA) often accounts for a large portion of the total fine aerosol burden (Jimenez et al., 2009), a fraction that has been increasing over time, particularly in regions where sulfur dioxide controls have reduced anthropogenic sources of sulfate (Marais et al., 2017). Characterizing aerosol impacts on air quality and climate thus requires a comprehensive understanding of the life cycle of organic aerosol in the atmosphere.

Organic aerosol that is emitted directly into the atmosphere from anthropogenic or natural sources is called primary organic aerosol (POA). A significant fraction of primary organic emissions has been shown to be semi-volatile, partitioning between the gas and particle phase depending on the ambient temperature and background organic aerosol concentration (Grieshop et al., 2009; Lipsky and Robinson, 2006; Robinson et al., 2007; Shrivastava et al., 2006). As these compounds are dispersed through the atmosphere, they are oxidized (in both the gas and particle phase) and typically form lower-volatility products. In addition to the primary component, organic aerosol is also generated dynamically in the atmosphere from volatile organic compound (VOC) and intermediate-volatility organic compound (IVOC) precursors that are both anthropogenic (e.g., benzene, toluene, xylene) and biogenic (e.g., isoprene, monoterpenes, sesquiterpenes). These gas-phase precursors undergo multi-phase, multigenerational oxidation processes that result in a complex array of semi-volatile species that partition into organic aerosol under conducive conditions. This class of aerosol products is called secondary organic aerosol (SOA). Both POA and SOA are important drivers of climate and air quality, often influencing regions far removed from their original source locations (Kanakidou et al., 2005).
Primary organic aerosol has traditionally been modeled as non-volatile (e.g., Chung and Seinfeld, 2002), but recent studies have incorporated a semi-volatile treatment that allows the aerosol species to dynamically partition between the condensed phase and gas phase, while simultaneously undergoing gas-phase oxidation to form organic compounds of lower volatility (Donahue et al., 2006; Robinson et al., 2007; Huffman et al., 2009; Pye and Seinfeld, 2010). There has been a similar evolution in the methods to model the formation and chemical processing of SOA in the atmosphere. Initial global modeling efforts often simulated SOA as a species that is directly formed upon the emission of various precursors, based on a fixed yield from laboratory or field studies (Chin et al., 2002; Kim et al., 2015; Pandis et al., 1992; Park et al., 2003). Many earth system models continue to use this simple approach (Tsigaridis et al., 2014). The twoproduct absorptive reversible partitioning scheme was then developed to account for the semi-volatile nature of SOA using lumped oxidation products from precursor VOCs (Odum et al., 1996; Pankow, 1994). Advances in computational resources have enabled recent studies to more effectively capture the volatility distribution of organics using a volatility basis set (VBS) of volatility-resolved semi-volatile surrogates that absorptively partition based on dry ambient OA concentrations (Donahue et al., 2006; Pye et al., 2010). There have also been more explicit chemical treatments of organic aerosol formation, such as those involving the implementation of a master chemical mechanism coupled with equilibrium absorptive partitioning and reactive surface uptake mechanisms (Li et al., 2015; Xia et al., 2008) or the explicit description of irreversible aqueous OA formation pathways (Fisher et al., 2016; Lin et al., 2012; Marais et al., 2016).

The wide range of VOC precursors, the complexities of the various formation pathways and the limited laboratory constraints on these processes make accurately modeling OA concentrations highly challenging. Previous model studies have identified large underestimates in the simulated OA when compared to observations (e.g., Heald et al., 2011; Volkamer et al., 2006). Over the past decade, the treatment of organic aerosol in chemical transport models has grown in complexity with models showing improved regional skill at simulating OA over areas like the southeast US (Marais et al., 2016; Budisulistiorini et al., 2017). However, studies that have evaluated OA model simulations against globally distributed measurements have demonstrated a consistent model inability to capture the magnitude and variability of observed OA concentrations (Heald et al., 2011; Tsigaridis et al., 2014). In particular, the evaluation by Heald et al. (2011) that used a two-product OA scheme revealed significant deficiencies in model skill and suggested that the GEOS-Chem model underestimated both the sources and sinks of OA at the global scale. The complex nature of OA formation and loss mechanisms in the atmosphere has thus made it difficult to constrain global models using a bottomup approach, particularly given the uncertainties inherent in 
the various emission inventories and chemical mechanisms. Here, we use a top-down approach, leveraging a suite of 15 aircraft campaigns to evaluate the two different organic aerosol schemes implemented within the standard GEOSChem chemical transport model in order to assess their relative strengths and weaknesses over a wide range of chemical and spatial regimes.

\section{Model description}

We use the chemical transport model GEOS-Chem (http: //www.geos-chem.org, last access: 5 January 2019) to simulate organic aerosol mass concentrations along the flight tracks of a suite of airborne campaigns described in Sect. 3. In order to contrast the different approaches to modeling organic aerosol and its precursors in the atmosphere, we perform a series of simulations from 2008 to 2017 using two distinct model schemes that vary based on their treatment of organic aerosol (see Sect. 2.1 and Table S1 in the Supplement).

$\begin{array}{lrlr}\text { These simulations } & \text { were } & \text { performed } & \text { with } \\ \text { the GEOS-Chem } & \text { model } & \text { version } & 12.1 .1\end{array}$
(https://doi.org/10.5281/zenodo.2249246; International GEOS-Chem User Community, 2018) with a horizontal resolution of $2^{\circ} \times 2.5^{\circ}$ and 47 vertical hybrid-sigma levels that extend from the surface to the lower stratosphere. A series of nested simulations, over North America and Asia, were performed at a higher spatial resolution of $0.5^{\circ} \times 0.625^{\circ}$ using boundary conditions from the $2^{\circ} \times 2.5^{\circ}$ global run. The model is driven by the MERRA- 2 assimilated meteorological product from the NASA Global Modeling and Assimilation Office (GMAO) with a transport time step of $10 \mathrm{~min}$ as recommended by Philip et al. (2016). The model includes a coupled treatment of $\mathrm{HO}_{x}-\mathrm{NO}_{x}-\mathrm{VOC}-\mathrm{O}_{3}$ chemistry (Mao et al., 2013; Travis et al., 2016; Chan Miller et al., 2017) with integrated $\mathrm{Cl}-\mathrm{Br}-\mathrm{I}$ chemistry (Sherwen et al., 2016) and uses a bulk aerosol scheme with fixed lognormal modes (Martin et al., 2003). GEOS-Chem simulates sulfate aerosol (Park, 2004), sea salt (Jaeglé et al., 2011), black carbon (Park et al., 2003) and mineral dust (Fairlie et al., 2007; Ridley et al., 2012). Ammonium and nitrate thermodynamics are described using the ISORROPIA II model (Fountoukis and Nenes, 2007). Deposition losses are dictated by aerosol and gas dry deposition to surfaces based on a resistor-in-series scheme (Wesely, 1989; Zhang et al., 2001) and wet deposition from scavenging by rainfall and moist convective cloud updrafts (Amos et al., 2012; Jacob et al., 2000; Liu et al., 2001). More details on the deposition schemes are provided in the Supplement.

\subsection{Organic aerosol simulations}

This study evaluates the two standard organic aerosol schemes within the GEOS-Chem model. The complex scheme represents a more detailed, recently updated treatment of organic aerosol in the atmosphere based on numerous laboratory studies and an explicit chemical mechanism for the oxidation of isoprene. The simple scheme is designed to serve as a computationally efficient alternative for approximating tropospheric OA concentrations without attempting to model the formation and fate of the various aerosol species mechanistically and without explicit thermodynamic partitioning. We note that the simple scheme was developed independently from the complex scheme and should not be regarded as a reduced version of the complex scheme. These schemes are described below and are graphically illustrated in Fig. 1.

The simple scheme treats all organic aerosol as nonvolatile. The POA consists of a hydrophobic "emitted" component (EPOA) with an assumed organic-mass-to-organiccarbon (OM : OC) ratio of 1.4 and a hydrophilic "oxygenated" component (OPOA) with an assumed OM:OC ratio of 2.1. Of the organic carbon emitted from primary sources, $50 \%$ is assumed to be hydrophilic (OPOA) to simulate the near-field oxidation of EPOA. The atmospheric aging of EPOA is modeled by its conversion to hydrophilic aerosol (OPOA) with an atmospheric lifetime of $1.15 \mathrm{~d}$, with no explicit dependence on local oxidant levels (Chin et al., 2002; Cooke et al., 1999). The EPOA and OPOA species are represented within the GEOS-Chem model using the variable names OCPO and OCPI, respectively. In addition, GEOSChem includes an online emission parameterization for submicron non-volatile marine primary organic aerosol (MPOA) as described in Gantt et al. (2015). The marine POA is emitted as hydrophobic (M-EPOA) and is aged in the atmosphere by its conversion to hydrophilic aerosol (M-OPOA), with the same $1.15 \mathrm{~d}$ lifetime. For the purpose of this study, the hydrophobic and hydrophilic components have been lumped together under the MPOA moniker.

The simple scheme uses a lumped SOA product (SOAS) with a molecular weight of $150 \mathrm{~g} \mathrm{~mol}^{-1}$ and an SOA precursor (SOAP) that is emitted from biogenic, pyrogenic and anthropogenic sources with fixed OA yields. For biogenic SOA, a $3 \%$ yield from isoprene (Kim et al., 2015) and $10 \%$ yield from both monoterpenes and sesquiterpenes (Chin et al., 2002) is assumed. SOA precursor emissions from combustion sources are estimated using $\mathrm{CO}$ emissions as a proxy, with a $1.3 \%$ scaled co-emission of SOAP from fire and biofuel $\mathrm{CO}$ and a $6.9 \%$ SOAP co-emission from fossil fuel CO (Cubison et al., 2011; Hayes et al., 2015; Kim et al., 2015). For biogenic SOA from isoprene, monoterpenes and sesquiterpenes, $50 \%$ is emitted directly as SOAS to account for the near-field formation of secondary organic aerosol. The SOAP converts to SOAS based on a first-order rate constant with a lifetime of $1 \mathrm{~d}$ as it is transported through the troposphere (Fig. 1).

For the purpose of this study, the default simple scheme in GEOS-Chem was modified to individually simulate $14 \mathrm{OA}$ lumped model tracers from anthropogenic, biogenic, marine 


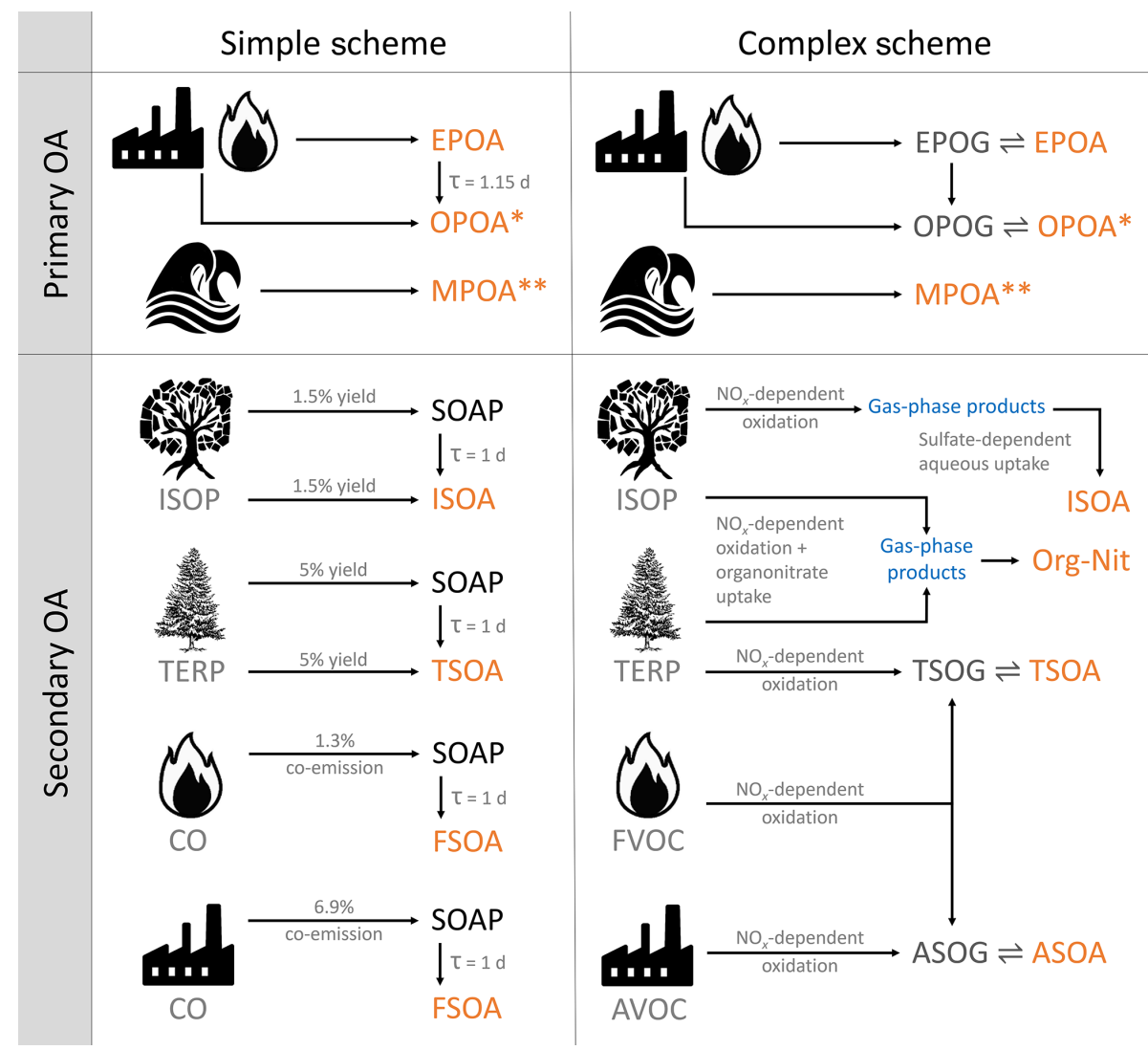

Figure 1. A graphical overview of the two organic aerosol model schemes in GEOS-Chem. TERP denotes monoterpenes and sesquiterpenes. Pyrogenic VOCs (FVOCs) denote the various volatile and semi-volatile organic compounds emitted from fires, while anthropogenic VOCs (AVOCs) are comprised of benzene, toluene, xylene and various intermediate-volatility organic compounds that are modeled using naphthalene as a proxy. OPOA* is sometimes classified as secondary organic aerosol from SVOCs. MPOA** denotes lumped marine POA consisting of both fresh (M-EPOA) and oxidized (M-OPOA) components. Species in orange contribute to OA; images modified from https://openclipart.org/ (last access: 11 January 2018) and https://publicdomainvectors.org/ (last access: 5 December 2019). See Sect. 2.1 in the text for details.

and pyrogenic sources. These consisted of six POA tracers, four SOA tracers and four SOA precursor tracers, allowing for the independent adjustment of parameters such as emission rates, yields, chemical lifetimes and deposition rates, enabling a robust testing of various sensitivities and OA source attributions.

The complex scheme, based primarily on Pye et al. (2010) and Marais et al. (2016), is graphically described in Fig. 1. The primary organics are treated as semi-volatile and allowed to reversibly partition between the aerosol (EPOA) and gas (EPOG) phase using a two-product reversible partitioning model while simultaneously undergoing oxidation with $\mathrm{OH}$ in the gas phase to form oxidized primary organic gases (OPOGs) that, in turn, reversibly partition to oxidized primary organic aerosols (OPOAs). Primary semi-volatile organic vapors that are oxidized to form lower-volatility products are sometimes classified as secondary organic aerosol (Murphy et al., 2014). However, for the purpose of this study, we define SOA as being formed exclusively from volatile precursors, while classifying the OA resulting from the oxidation of primary organic compounds as OPOA, in order to be consistent with previous model studies using GEOSChem (Pye et al., 2010). Model EPOG emissions are based on the EPOA inventories used in the simple scheme and have been scaled up by $27 \%$ to account for semi-volatile organic matter emitted in the gas phase (Pye et al., 2010; Schauer et al., 2001). As in the simple scheme, the EPOA and OPOA are assumed to have an OM : OC ratio of 1.4 and 2.1, respectively. The complex scheme also includes the non-volatile MPOA simulation as described above.

SOA formation from anthropogenic, pyrogenic and select biogenic precursors is based on the VBS outlined in Pye et al. (2010) that oxidizes gas-phase SOA precursors (with oxidants $\left.-\mathrm{OH}, \mathrm{O}_{3}\right)$ to form alkyl peroxy $\left(\mathrm{RO}_{2}\right)$ radicals that react with either $\mathrm{HO}_{2}$ or NO. The SOA formed from these second-generation products depends on the $\mathrm{NO}_{x}$ regime - with high and low $\mathrm{NO}_{x}$ yields and partitioning coefficients based on experimental fits from laboratory stud- 
ies. The resulting products are classified into two categories based on the origins of their precursors, anthropogenic SOA (ASOA; formed from the oxidation of light aromatic compounds) and terpene SOA (TSOA; formed from the oxidation of monoterpenes and sesquiterpenes), that dynamically partition between the aerosol and gas phases based on their saturation vapor pressures and ambient aerosol concentrations. Aerosol formed from intermediate-volatility organic compounds (IVOCs) is modeled using naphthalene as a proxy that, when oxidized, contributes to the ASOA lumped product. A comprehensive overview of the VBS scheme can be found in Pye et al. (2010).

The complex scheme builds on this VBS framework by incorporating aerosol formed irreversibly from the aqueousphase reactive uptake of isoprene (Marais et al., 2016) and the formation of organo-nitrates (Org-Nit) from both isoprene and monoterpene precursors (denoted in Fig. 1) based on work by Fisher et al. (2016). These mechanisms replace the "pure-VBS" treatment of isoprene SOA (ISOA) and organic nitrates (formed from the oxidation of isoprene and monoterpenes by $\mathrm{NO}_{3}$ ) from Pye et al. (2010). The total organic aerosol loadings in the complex scheme are thus comprised of the EPOA, OPOA, ASOA and TSOA species in addition to the various products resulting from the isoprene and monoterpene organo-nitrate oxidation pathways (organic nitrates from isoprene and monoterpene precursors, aerosol-phase glyoxal, methylglyoxal, isoprene epoxydiols - IEPOX, $\mathrm{C}_{4}$ epoxides, organo-nitrate hydrolysis products, second-generation hydroxy-nitrates, and low-volatility nonIEPOX products of isoprene hydroxy hydroperoxide oxidation), lumped here as ISOA and Org-Nit. ISOA and Org-Nit are generated exclusively through the aqueous uptake pathway and do not include any "nonaqueous" OA. The model does not explicitly consider cloud processing of SOA. More information on the treatment of OA in the complex scheme can be found in the Supplement.

In order to conduct a comparison with a VBS treatment of isoprene SOA (as described in Pye et al., 2010), an analysis was also conducted with the isoprene SOA forming exclusively through the VBS (referred to here as pure VBS).

\subsection{Emissions}

Global annual mean emissions of key species for a single simulation year (2013) are shown in Table 1. The corresponding emissions (and atmospheric sources) for OA species are shown in Table 2. Year-specific pyrogenic emissions are simulated at a $3 \mathrm{~h}$ resolution from the GFED4s satellitederived global fire emissions database (van der Werf et al., 2017). Global anthropogenic emissions follow the Community Emissions Data System (CEDS) inventory (Hoesly et al., 2018). Anthropogenic IVOC emissions are estimated using naphthalene as a proxy (see the Supplement for more information), which is assumed to have the same spatial distribution as benzene and is scaled from the CEDS inventory using
Table 1. Global annual mean emissions of SOA precursors and relevant species used in the GEOS-Chem simulation for the year 2013.

\begin{tabular}{lr}
\hline Species & $\begin{array}{r}\text { Annual global } \\
\text { emissions }\left(\mathrm{Tg} \mathrm{yr}^{-1}\right)\end{array}$ \\
\hline Total aromatics & 25.6 \\
Anthropogenic & 23.5 \\
Pyrogenic & 2.1 \\
\hline IVOCs & 5.43 \\
\hline Isoprene & 385.3 \\
\hline Terpenes & 153.6 \\
\hline Total CO & 891.2 \\
Anthropogenic & 593.0 \\
Pyrogenic & 298.2 \\
\hline Total NO ${ }_{x}$ & 111.7 \\
Anthropogenic & 70.7 \\
Pyrogenic & 12.1 \\
Lightning & 12.7 \\
Soil and fertilizer & 16.2 \\
\hline
\end{tabular}

the same approach as Pye and Seinfeld (2010). These emissions are overwritten with regional inventories when available, such as the National Emissions Inventory (NEI 2011) for the US (as described by Travis et al., 2016), the Big Bend Regional Aerosol and Visibility Observational (BRAVO) inventory for Mexico (Kuhns et al., 2005), the Criteria Air Contaminants (CAC) inventory for Canada (https://www. canada.ca/en/environment-climate-change.html, last access: 5 December 2019), the European Monitoring and Evaluation Programme (EMEP) inventory for Europe (http://www. emep.int/, last access: 5 December 2019), the Diffuse and Inefficient Combustion Emissions (DICE) inventory for Africa (Marais and Wiedinmyer, 2016) and the MIX inventory for Asian emissions ( $\mathrm{Li}$ et al., 2017). In addition to the anthropogenic and pyrogenic inventories listed above, nitrogen oxides are also emitted from lightning (Murray et al., 2012; Ott et al., 2010), soil (Hudman et al., 2012) and ship (Holmes et al., 2014) sources. Biogenic emissions for isoprene and terpene species in GEOS-Chem are based on the coupled ecosystem emissions model MEGAN (Model of Emissions of Gases and Aerosols from Nature) v2.1 (Guenther et al., 2012). All emissions are managed via the Harvard-NASA Emissions Component (HEMCO) module (Keller et al., 2014). We note that given the interannual variability in emissions, particularly from fires, the emissions for years other than 2013 may differ somewhat from the values shown in Tables 1 and 2.

In the simple scheme, $50 \%$ of the primary OA is emitted as EPOA and $50 \%$ is emitted as OPOA to approximate the near-field aging of EPOA. Total OC emissions are $31.2 \mathrm{Tg}$ C. Given the OC: OM ratios of 1.4 and 2.1 assumed for EPOA and OPOA, respectively, total POA emissions in the sim- 
Table 2. Annual mean simulated global source, burden, lifetime (against physical deposition), and wet and dry deposition rates for the individual OA species averaged over 2013 for the complex and simple schemes.

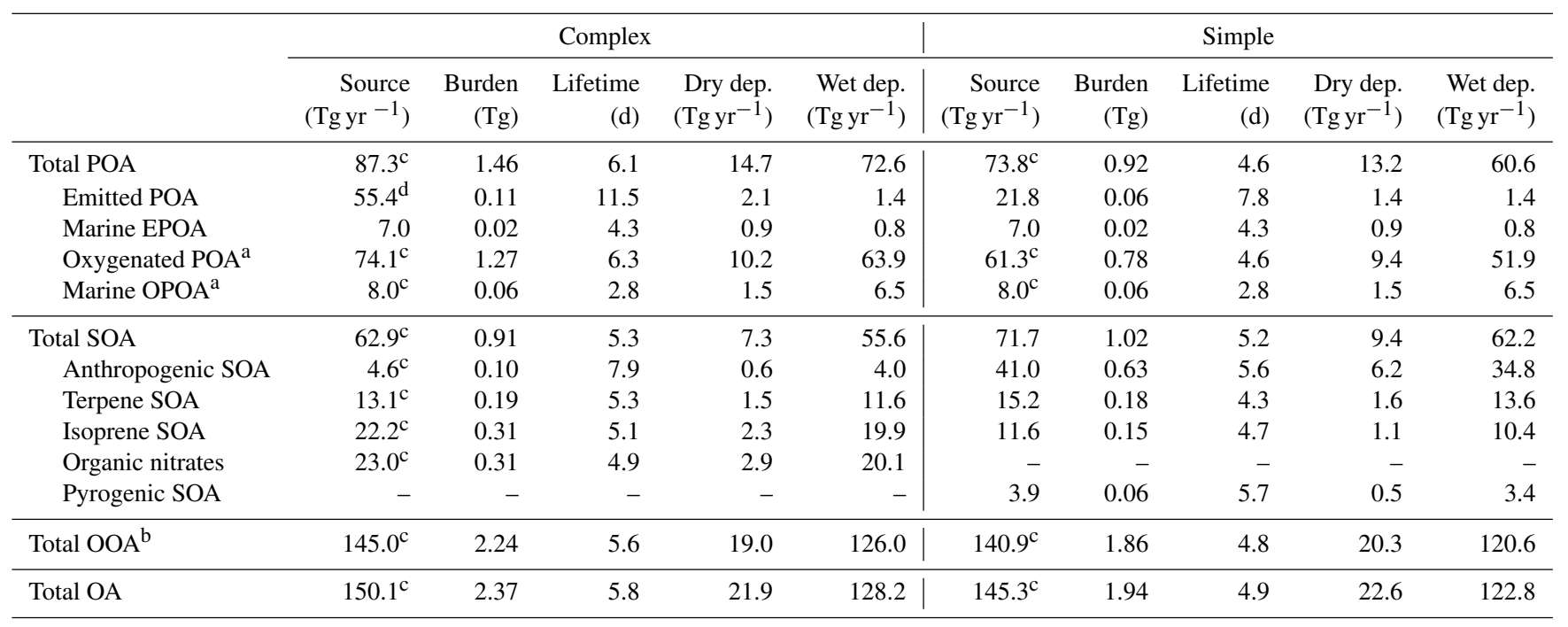

${ }^{a}$ SVOCs from primary sources that are oxidized in the atmosphere, sometimes classified as SOA. ${ }^{b}$ OOA (oxygenated organic aerosol) $=$ OPOA $+\mathrm{M}-\mathrm{OPOA}+\mathrm{SOA}$.

c Calculated based on a steady-state assumption with depositional losses in order to account for atmospheric formation. The total POA source is not the direct sum of the individual POA sources since a significant fraction of EPOA and MPOA forms OPOA and M-OPOA, respectively. See Sect. 2.2 for emissions totals and more information. ${ }^{\mathrm{d}}$ Primary organic emissions in the complex scheme are in the gas phase (EPOG), while primary organic emissions in the simple scheme are in the form of non-volatile particulate. An OM : OC

ratio of 1.4 is assumed for the EPOG and EPOA species, while an OM : OC ratio of 2.1 is assumed for the OPOA species.

ple scheme are $21.8 \mathrm{Tg}$ EPOA and $32.8 \mathrm{Tg}$ OPOA for a total annual POA emission of $54.6 \mathrm{Tg}$. We note that OPOA emissions in the simple scheme are a subset of the sources listed in Table 2 since they do not include atmospheric formation through the oxidative aging of EPOA. In the complex scheme, all POA is emitted as gas-phase EPOG after scaling the same inventory used in the simple scheme by $27 \%$ to account for the extra gas-phase material. Total primary emissions in the complex scheme are thus exclusively from EPOG gas-phase emissions and amount to 55.4 $\mathrm{Tg} \mathrm{yr}^{-1}$. Both schemes emit an additional 7.0 $\mathrm{Tg}^{-1}$ of OA from marine sources. The simple scheme also directly emits $71.7 \mathrm{Tg} \mathrm{yr}^{-1}$ of SOA (in the form of SOAS and SOAP), over half of which comes from anthropogenic sources. The total OA source (POA + SOA; includes direct emissions and atmospheric formation) in both the complex and simple schemes (150.1 and $145.3 \mathrm{Tg} \mathrm{yr}^{-1}$, respectively; Table 2) is greater than the ensemble median OA source of around $100 \mathrm{Tg} \mathrm{yr}^{-1}$ calculated by Tsigaridis et al. (2014) across a set of various global models.

\subsection{Model evaluation}

Two primary metrics have been used through this study to evaluate model performance compared to ambient observations (see Sect. 3) - the coefficient of determination $\left(R^{2}\right)$ and the normalized mean bias (NMB). The coefficient of determination is defined by the regression fit using Eq. (1) and can be interpreted as the proportion of the variance in the observational data that is accurately captured by the model. The normalized mean bias is calculated using Eq. (2). A positive NMB indicates that the model is biased high on average and vice versa.

Coefficient of determination

$\left(R^{2}\right)=1-\frac{\text { Residual sum of squares }}{\text { Total sum of squares }}$

Normalized mean bias

$$
(\mathrm{NMB})=\frac{\sum_{1}^{n}(\text { model }- \text { observation })}{\sum_{1}^{n}(\text { observation })}
$$

\section{Description of observations}

For the purposes of evaluating the GEOS-Chem model, we focus on airborne data that provide regional 3-D sampling and reduce the challenges associated with model representation error at single sites. We further define a set of observations that make use of a single measurement technique, are publicly accessible and do not extend beyond the last decade. The resulting observations are from 15 aircraft campaigns conducted between 2008 and 2017 and cover a wide range of geographic locations and chemical regimes. Table 3 provides a brief overview of the various campaigns included here, and Fig. 2 shows the spatial extent of the individual flight tracks. Aerosol concentrations were measured using aerosol mass 


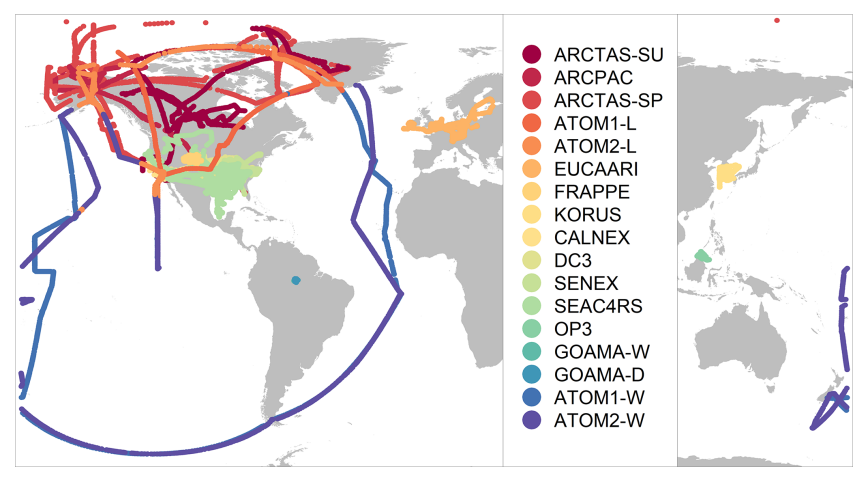

Figure 2. Location of flight tracks for the airborne field campaigns.

spectrometers (AMSs) (Jayne et al., 2000; Canagaratna et al., 2007) with small variations in the instrumentation and aircraft inlet configurations between the different campaigns (as referenced in Table 3). The AMS measures submicron nonrefractory dry aerosol mass and is estimated to have an uncertainty of $34 \%-38 \%$, depending on the species (Bahreini et al., 2009). All concentration measurements in this study have been converted to standard conditions of temperature and pressure (STP: $273 \mathrm{~K}, 1 \mathrm{~atm} ; \mu \mathrm{g} \mathrm{sm}^{-3}$ ). In addition to organic aerosol mass loadings, concentrations of other species, such as nitrogen oxides, carbon monoxide, isoprene and sulfate, are used in this study to validate chemical regimes (see Sect. 4.2). Table S2 provides an overview of the instrumentation and associated primary investigators for the organic aerosol and trace gas observations. Environmental and meteorological measurements such as temperature and relative humidity are also used in the analysis.

Observations are gridded to the GEOS-Chem model resolution of $2^{\circ} \times 2.5^{\circ}$ (or alternatively to $0.5^{\circ} \times 0.625^{\circ}$ for comparisons with nested simulations) and are averaged over the model time step of $10 \mathrm{~min}$ in cases in which multiple observations were conducted within the span of a single time step (see the Supplement for more details on model sampling). In order to limit the impact of localized plumes, in particular from fires, we filter the observations to remove concentrations over the 97th percentile for each campaign, eliminating measurements that can often exceed $500 \mu \mathrm{g} \mathrm{sm}^{-3}$. This enables a more fair comparison with the model by disregarding the impact of sub-grid features that cannot be reproduced by an Eulerian model (Rastigejev et al., 2010). Following the averaging process, we obtain a merged dataset of over 25000 unique points, with a broad spatial extent (Fig. 2) covering a variety of chemical regimes representing anthropogenic, pyrogenic, biogenic and remote environments. Despite the large temporal range of the observational dataset, most of the campaigns analyzed in this study were conducted during the spring and summer seasons, limiting the ability to perform a seasonal analysis.

Based on the proximity to emission sources and exposure to long-range pollutants, there is significant variation in the observed mean, medians and standard deviations across the different campaigns (Table 3, Fig. S1). The campaigns are also influenced by different OA sources depending on their sampling region. The EUCAARI campaign over western Europe (Morgan et al., 2010), KORUS-AQ over the Korean Peninsula (Nault et al., 2018), CalNex over California (Ryerson et al., 2013), and DC3 (Barth et al., 2014) and FRAPPE over the central US (Dingle et al., 2016) sample over regions that are heavily influenced by anthropogenic emissions. In contrast, the GoAmazon campaigns during the wet and dry seasons (Martin et al., 2016; Shilling et al., 2018) over the Manaus region in the Amazon and the OP3 campaign (Hewitt et al., 2010) over equatorial forests in southeast Asia are heavily influenced by biogenic emissions, although the GoAmazon campaign in the dry season is also strongly influenced by biomass burning. Additionally, data from both seasons of the GoAmazon campaign are influenced by anthropogenic urban outflow from Manaus (Shilling et al., 2018). Campaigns like SENEX (Warneke et al., 2016) and SEAC4RS (Toon et al., 2016) that conducted measurements over the southeast US are influenced by both anthropogenic and biogenic emissions, while the ARCPAC campaign (Brock et al., 2011) during the spring and the ARCTAS (Jacob et al., 2010) campaign during the spring and summer over the northern latitudes are strongly influenced by pyrogenic emissions from forest fires (particularly during the summer) and aged anthropogenic and biogenic emissions over the Arctic region. The KORUS-AQ campaign also includes a short deployment over California. However, for the purpose of this study, we restrict observations from this campaign to those over the Korean Peninsula. Lastly, the dataset includes measurements from the ATom-1 and ATom-2 campaigns (Wofsy et al., 2018). We divide the ATom campaigns into two datasets using a land mask in order to separate the observations of remote, well-mixed air masses over the Atlantic and the Pacific from near-source measurements over North America.

Figure 3 demonstrates that organic aerosol accounts for a significant portion (52\% on average) of the total nonrefractory aerosol mass loadings measured by AMS across all of the campaigns. The GoAmazon measurements during the dry season have the highest contribution of OA to the total submicron aerosol loading ( $77 \%$ ), while the ARCTAS campaign during the spring has the lowest OA contribution of any campaign $(31 \%)$.

\section{Results and discussion}

\subsection{Simulated OA budget}

Figure 4 shows the global annual mean simulated surface OA concentrations and global annual mean burdens using the simple and complex schemes for the year 2013 (burden numbers are provided in Table 2). The complex scheme simulates a larger annual mean OA burden than the simple 
Table 3. Aircraft measurements of organic aerosol used in this analysis. The statistical metrics for OA provided here (mean, median, standard deviation) are based on filtered data for each campaign (as discussed in the text; units: $\mu \mathrm{g} \mathrm{m}^{-3}$ ).

\begin{tabular}{|c|c|c|c|c|c|}
\hline Campaign & Dates (UTC, mm/dd) & Region & Abbreviation & $\begin{array}{l}\text { Measurement } \\
\text { technique }\end{array}$ & $\begin{array}{r}\text { Mean, median, } \\
\text { SD }\end{array}$ \\
\hline $\begin{array}{l}\text { ARCPAC } \\
\text { (Brock et al., 2011) }\end{array}$ & 2008 spring $(03 / 29-04 / 24)$ & Arctic, North America & - & C-ToF-AMS & $1.9,0.9,2.1$ \\
\hline $\begin{array}{l}\text { ARCTAS } \\
\text { (Jacob et al., 2010) }\end{array}$ & 2008 spring $(04 / 01-04 / 20)$ & Arctic, North America & ARCTAS-SP & HR-ToF-AMS & $0.7,0.4,0.9$ \\
\hline $\begin{array}{l}\text { ARCTAS } \\
\text { (Jacob et al., 2010) }\end{array}$ & 2008 summer $(06 / 18-07 / 13)$ & Arctic, North America & ARCTAS-SU & HR-ToF-AMS & $3.2,0.9,5.1$ \\
\hline $\begin{array}{l}\text { EUCAARI } \\
\text { (Morgan et al., 2010) }\end{array}$ & 2008 spring $(05 / 06-05 / 22)$ & Northwest Europe & - & C-ToF-AMS & $2.5,2.4,2.0$ \\
\hline $\begin{array}{l}\text { OP3 } \\
\text { (Hewitt et al., 2010) }\end{array}$ & 2008 summer $(07 / 10-07 / 20)$ & Borneo & - & C-ToF-AMS & $0.4,0.1,0.5$ \\
\hline $\begin{array}{l}\text { CalNex } \\
\text { (Ryerson et al., 2013) }\end{array}$ & 2010 spring and summer $(04 / 30-06 / 22)$ & Southwest US & - & C-ToF-AMS & $1.3,0.8,1.4$ \\
\hline $\begin{array}{l}\text { DC3 } \\
\text { (Barth et al., 2014) }\end{array}$ & 2012 spring and summer $(05 / 18-06 / 23)$ & Central US & - & HR-ToF-AMS & $2.5,1.4,2.4$ \\
\hline $\begin{array}{l}\text { SENEX } \\
\text { (Warneke et al., 2016) }\end{array}$ & 2013 summer (06/03-07/10) & Southeast US & - & C-ToF-AMS & $5.3,4.7,3.7$ \\
\hline $\begin{array}{l}\text { SEAC4RS } \\
\text { (Toon et al., 2016) }\end{array}$ & 2013 summer and fall (08/06-09/24) & Southeast, west US & - & HR-ToF-AMS & $3.2,0.6,4.6$ \\
\hline $\begin{array}{l}\text { GoAmazon } \\
\text { (Shilling et al., 2018) }\end{array}$ & 2014 wet season $(02 / 22-03 / 23)$ & Amazon & GOAMA-W & HR-ToF-AMS & $1.0,0.9,0.6$ \\
\hline $\begin{array}{l}\text { FRAPPE } \\
\text { (Dingle et al., 2016) }\end{array}$ & 2014 summer (07/26-08/19) & Central US & - & C-ToF-mAMS & $2.7,2.5,1.4$ \\
\hline $\begin{array}{l}\text { GoAmazon } \\
\text { (Shilling et al., 2018) }\end{array}$ & 2014 dry season $(09 / 06-10 / 04)$ & Amazon & GOAMA-D & HR-ToF-AMS & $4.6,4.6,1.8$ \\
\hline $\begin{array}{l}\text { KORUS-AQ } \\
\text { (Nault et al., 2018) }\end{array}$ & 2016 spring and summer $(05 / 03-06 / 10)$ & South Korea & KORUS & HR-ToF-AMS & $4.8,2.4,5.5$ \\
\hline $\begin{array}{l}\text { ATom } \\
\text { (Wofsy et al., 2018) }\end{array}$ & 2016 summer $(07 / 29-08 / 20)$ & $\begin{array}{l}\text { Remote ocean } \\
\text { North America }\end{array}$ & $\begin{array}{l}\text { ATOM1-W } \\
\text { ATOM1-L }\end{array}$ & HR-ToF-AMS & $\begin{array}{l}0.1,0.1,0.2 \\
0.5,0.2,0.8\end{array}$ \\
\hline $\begin{array}{l}\text { ATom } \\
\text { (Wofsy et al., 2018) }\end{array}$ & 2017 spring $(01 / 26-02 / 21)$ & $\begin{array}{l}\text { Remote ocean } \\
\text { North America }\end{array}$ & $\begin{array}{l}\text { ATOM2-W } \\
\text { ATOM2-L }\end{array}$ & HR-ToF-AMS & $\begin{array}{l}0.1,0.1,0.1 \\
0.1,0.1,0.1\end{array}$ \\
\hline Aggregate & & & & & $2.4,0.7,3.6$ \\
\hline
\end{tabular}

scheme (2.37 Tg compared to $1.94 \mathrm{Tg}$ ). This is largely due to the scaled emissions of the primary organic gases in the complex scheme (greater by a factor of $27 \%$ ) as well as the semivolatile treatment of the EPOA/EPOG and OPOA/OPOG species, which substantially extends their tropospheric residence time due to the longer lifetime of the gas-phase component in the boundary layer. As a result, the complex scheme simulates a larger POA burden (EPOA + OPOA + MPOA) of $1.46 \mathrm{Tg}$, compared to $0.92 \mathrm{Tg}$ POA in the simple scheme. The majority $(91.4 \%)$ of the POA in the complex scheme consists of oxidized POA and oxidized MPOA (M-OPOA) that, given its aged and chemically processed nature, is often indistinguishable from secondary organic aerosol with typical AMS measurements (Jimenez et al., 2009). Consequently, $94.7 \%$ of the global OA burden in the complex scheme is oxygenated organic aerosol $(\mathrm{OOA}=\mathrm{OPOA}+\mathrm{M}-$ OPOA + SOA; Table 2). Similarly, $91.7 \%$ of the total POA burden and $96.1 \%$ of the total OA burden are oxygenated in the simple scheme.

Both the complex and simple schemes simulate comparable global SOA burdens ( 0.91 and $1.02 \mathrm{Tg}$, respectively). However, the complex scheme produces more isoprenederived SOA (ISOA) and biogenic organo-nitrates (Org-Nit) than the simple scheme (Fig. 4d), particularly over areas with elevated isoprene and anthropogenic sulfate concentrations (such as the southeast US and southeast Asia) since 


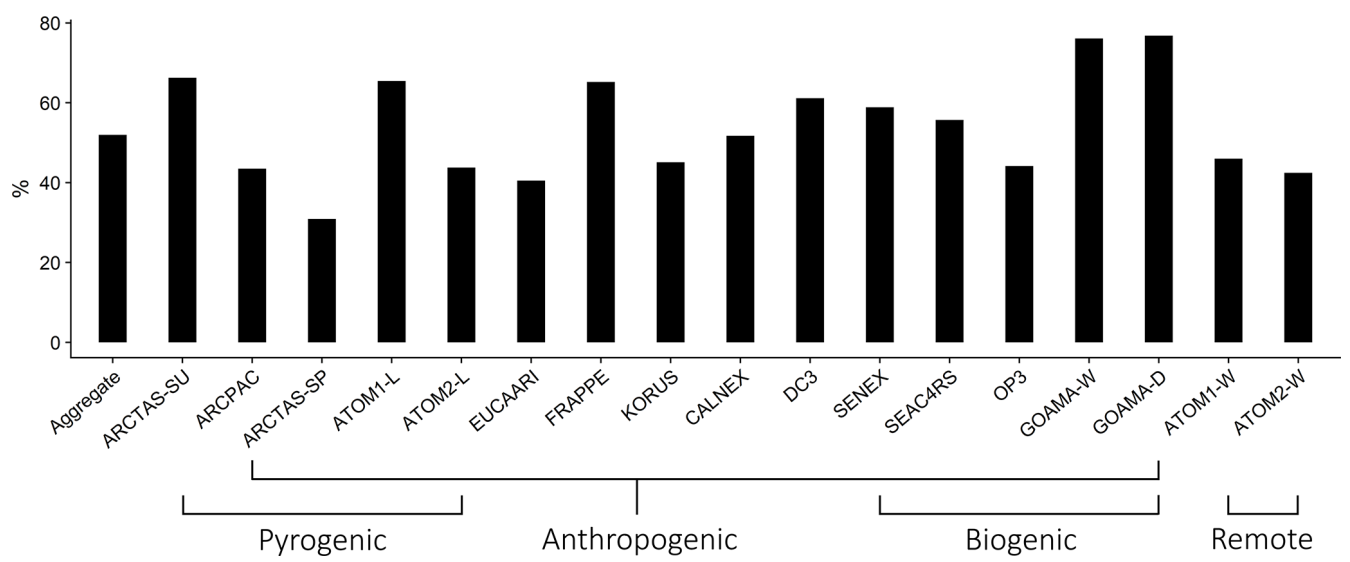

Figure 3. The percentage contribution of organic aerosol by mass to the total observed non-refractory mass concentrations measured by the AMS; organized by campaign. This includes aerosol mass from organic aerosol, sulfate, nitrate and ammonium. Campaigns are broadly organized based largely on model-characterized source influence. However, as noted in the text, this characterization is often not indicative of the true sampling profile. For instance, the GoAmazon campaigns sampled heavily from fire and anthropogenic sources in addition to being strongly influenced by biogenic sources.

(a)

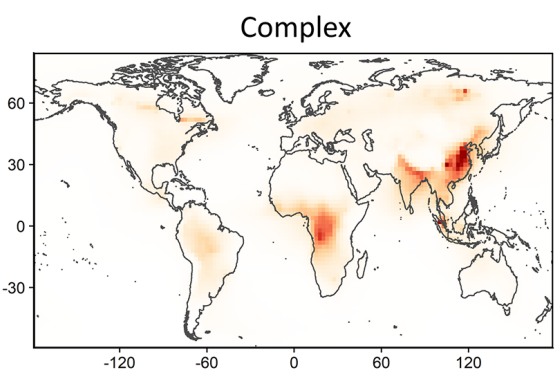

(c)

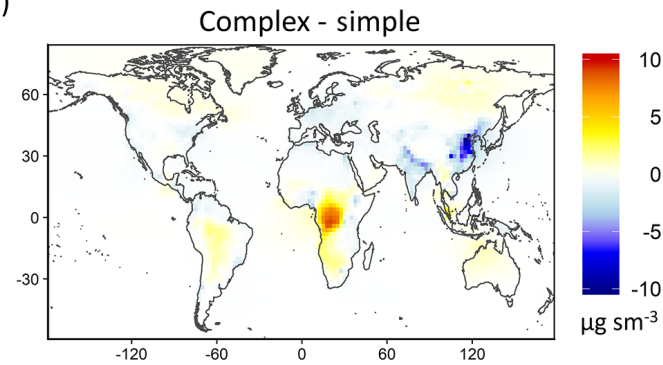

(b)
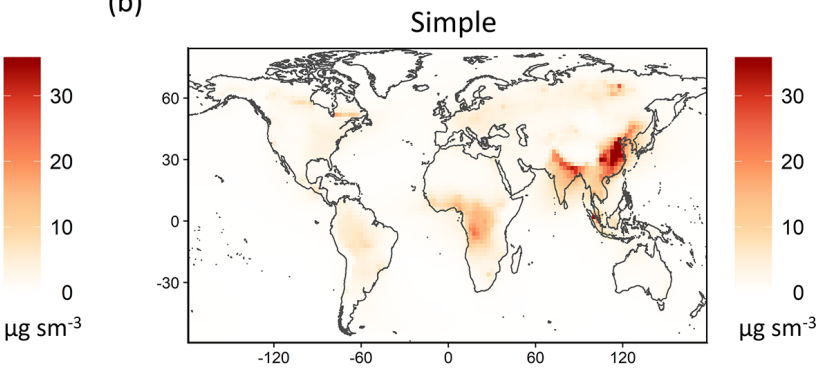

(d)

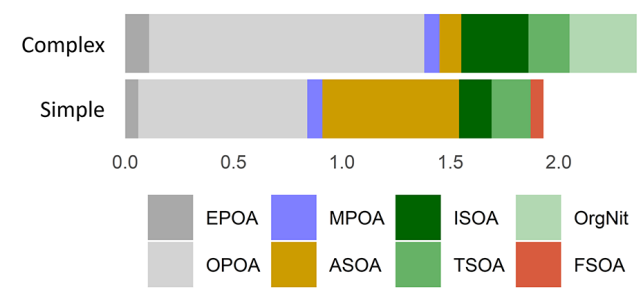

Figure 4. Global map of simulated OA surface concentrations in 2013 for the (a) complex and (b) simple schemes; panel (c) illustrates the difference in OA surface loadings between the complex and simple schemes. Panel (d) displays the total global burden for the individual OA species from both schemes averaged over 2013. Refer to Sect. 3 for details on model sampling and averaging.

the ISOA formation is acid-catalyzed. The explicit aqueous uptake mechanism for the isoprene-derived SOA products also results in substantially larger global isoprene SOA burdens $(0.31 \mathrm{Tg})$ when compared to the pure-VBS treatment of isoprene-derived SOA that simulates an annually averaged ISOA burden of $0.12 \mathrm{Tg}$. This is consistent with other comparisons that have shown that the VBS treatment in GEOS-Chem underpredicts observed ISOA concentrations compared to the complex treatment (Jo et al., 2019). Despite the different treatments, both the complex and simple schemes have similar terpene-derived SOA (TSOA) burdens at 0.19 and $0.18 \mathrm{Tg}$, respectively (Table 2).

Anthropogenic SOA (ASOA) is a particularly important global OA source in the simple scheme, accounting for almost a third of the total OA burden. The simple scheme, with its near-field formation of SOA proportional to anthropogenic $\mathrm{CO}$ emissions, simulates a substantially larger ASOA burden than the complex scheme $(0.63$ vs. $0.10 \mathrm{Tg}$; Table 2), particularly over industrialized regions in Asia (Fig. 4c). Previous studies that have constrained global 
SOA burdens using observed mass loadings have proposed a missing model SOA source over anthropogenic regions (Spracklen et al., 2011), as have recent regional studies (Schroder et al., 2018; Shah et al., 2019). The simple scheme appears to capture a greater fraction of this missing burden. However, we note that ASOA yields in the simple scheme are based on a lumped parameterization over the Los Angeles basin (Hayes et al., 2015) and might not be representative of global yields across different chemical regimes. The global ASOA burden of $0.63 \mathrm{Tg}$ is 4 times greater than the ASOA burden proposed by Spracklen et al. (2011), but it is well within the "anthropogenically controlled" SOA burden proposed by the same study. This suggests that the simple parametrization in its current form might unintentionally represent some anthropogenically controlled biogenic SOA. Additionally, while the simple scheme includes separate SOA yield parameters for fossil fuel and biofuel combustion, the emissions inventories used in this study do not always explicitly differentiate between the two sources. As a consequence, biofuel is often lumped together with fossil fuel CO, potentially leading to an overestimate in ASOA yields from biofuel emissions.

Pye and Seinfeld (2010) performed a similar analysis of tropospheric OA burdens using a semi-volatile POA treatment and a pure-VBS treatment of SOA (i.e., all SOA treated in the VBS, including isoprene) with the GEOS-Chem model (v8.01.04). Their model simulated $0.03 \mathrm{Tg}$ EPOA, $0.81 \mathrm{Tg}$ OPOA and $0.80 \mathrm{Tg}$ SOA compared to $0.11 \mathrm{Tg}$ EPOA, $1.27 \mathrm{Tg}$ OPOA and $0.91 \mathrm{Tg}$ SOA for the complex scheme and $0.06 \mathrm{Tg}$ EPOA, $0.78 \mathrm{Tg}$ OPOA and $1.02 \mathrm{Tg}$ SOA for the simple scheme in this study. When compared to an analysis of organic aerosol loadings from 31 different chemical transport and general circulation models (Tsigaridis et al., 2014), the primary OA burden from the complex scheme $(\mathrm{EPOA}+\mathrm{MPOA}+\mathrm{OPOA})$ is substantially higher than most of the models surveyed, while the SOA burden falls below the mean but above the median of the distribution. The simple scheme, with a much smaller POA burden, is approximately on par with the Tsigaridis et al. (2014) ensemble mean. The simple SOA burden is roughly equivalent to the Tsigaridis et al. (2014) model mean (but significantly greater than the median) for global SOA loadings.

Aerosol lifetimes are calculated using the ratio between the mass burden and the physical loss rates due to dry and wet deposition (Table 2). POA in the complex scheme has an average lifetime to physical loss of $6.1 \mathrm{~d}\left(\tau_{\mathrm{EPOA}} \sim 11.5 \mathrm{~d}\right.$, $\left.\tau_{\mathrm{OPOA}} \sim 6.3 \mathrm{~d}, \tau_{\mathrm{MPOA}} \sim 3.0 \mathrm{~d}\right)$ in the atmosphere, while SOA has a lifetime of $5.3 \mathrm{~d}$ on average $\left(\tau_{\mathrm{ASOA}} \sim 7.9 \mathrm{~d}\right.$, $\left.\tau_{\text {TSOA }} \sim 5.3 \mathrm{~d}, \tau_{\text {ISOA }} \sim 5.1 \mathrm{~d}, \tau_{\text {ORG-NIT }} \sim 4.9 \mathrm{~d}\right)$. POA in the simple scheme has an average global lifetime of $4.6 \mathrm{~d}$ $\left(\tau_{\mathrm{EPOA}} \sim 7.8 \mathrm{~d}, \tau_{\mathrm{OPOA}} \sim 4.6 \mathrm{~d}, \tau_{\mathrm{MPOA}} \sim 3.0 \mathrm{~d}\right)$, while the parameterized SOA species have an average lifetime of $5.2 \mathrm{~d}\left(\tau_{\mathrm{ASOA}} \sim 5.6 \mathrm{~d}, \tau_{\mathrm{TSOA}} \sim 4.3 \mathrm{~d}, \tau_{\mathrm{ISOA}} \sim 4.7 \mathrm{~d}\right)$. $\mathrm{POA}$ lifetimes in both the complex and simple schemes are similar to the simulated POA lifetimes from Tsigaridis et al. (2014), who calculated an ensemble mean POA lifetime of approximately $5 \mathrm{~d}$. SOA lifetimes from this study are lower than the ensemble mean of $8 \mathrm{~d}$ calculated by Tsigaridis et al. (2014). The range in aerosol lifetimes can be attributed to several different factors. The hydrophobic nature of EPOA leads to longer lifetimes against wet deposition since the particles are unaffected by rainout. The spatial distribution of the different aerosol types also plays an important role in determining their lifetimes, with species emitted over marine-tropical regions experiencing a higher likelihood of being deposited via wet deposition than aerosol over drier regions. Surface land types also affect dry deposition velocities, impacting aerosol lifetimes. In addition, there is a marked difference in lifetimes between the semi-volatile species in the complex scheme and non-volatile species in the simple scheme. Due to the temperature-dependent partitioning, the semi-volatile aerosol species are often in the gas phase in the warmer parts of the troposphere and are advected to higher altitudes before they partition to aerosol. The non-volatile species do not simulate this process and are more likely to be deposited before they can be transported to higher altitudes.

\subsection{Regime analysis}

We use the observations from the 15 field campaigns described in Sect. 3 as a single coherent dataset. Given the wide range of chemical regimes sampled by the various field campaigns, a method for classifying the observations is needed to better inform the model-measurement comparisons. While the chemical composition of the observed OA can provide some insight into source types or aging, a comprehensive classification is not possible using only the observations, requiring that we rely on the model for such a segmentation. In this analysis, we use the relative dominance of the different OA species within the GEOS-Chem simple scheme simulation to classify the measurements into different regimes (described in Table S3 in the Supplement). The sorting algorithm weights the relative importance of the three $\mathrm{OA}$ source types - anthropogenic (A), biogenic (B) and pyrogenic (F) based on their relative contribution by mass to the total OA loading in the model. Any data point with a source contribution greater than $70 \%$ of the total organic mass loading is categorized as being dominated by that source (such as A for anthropogenic). Although this threshold limit is somewhat arbitrary, an analysis of different threshold values between $60 \%$ and $80 \%$ shows that the resulting classifications are not particularly sensitive to changes within this range. Data points without a single dominant source but with two large sources, contributing greater than $85 \%$ of the total OA mass, are classified into a second type of regime category (such as $\mathrm{AB}$ for anthropogenic-biogenic), and points without any dominant $\mathrm{OA}$ source types are classified into the mixed regime category (AFB). Points with an aggregate OA mass concentration below $0.2 \mu \mathrm{g} \mathrm{sm}^{-3}$ across the three source types are classified as "remote-marine". Points for which MPOA con- 


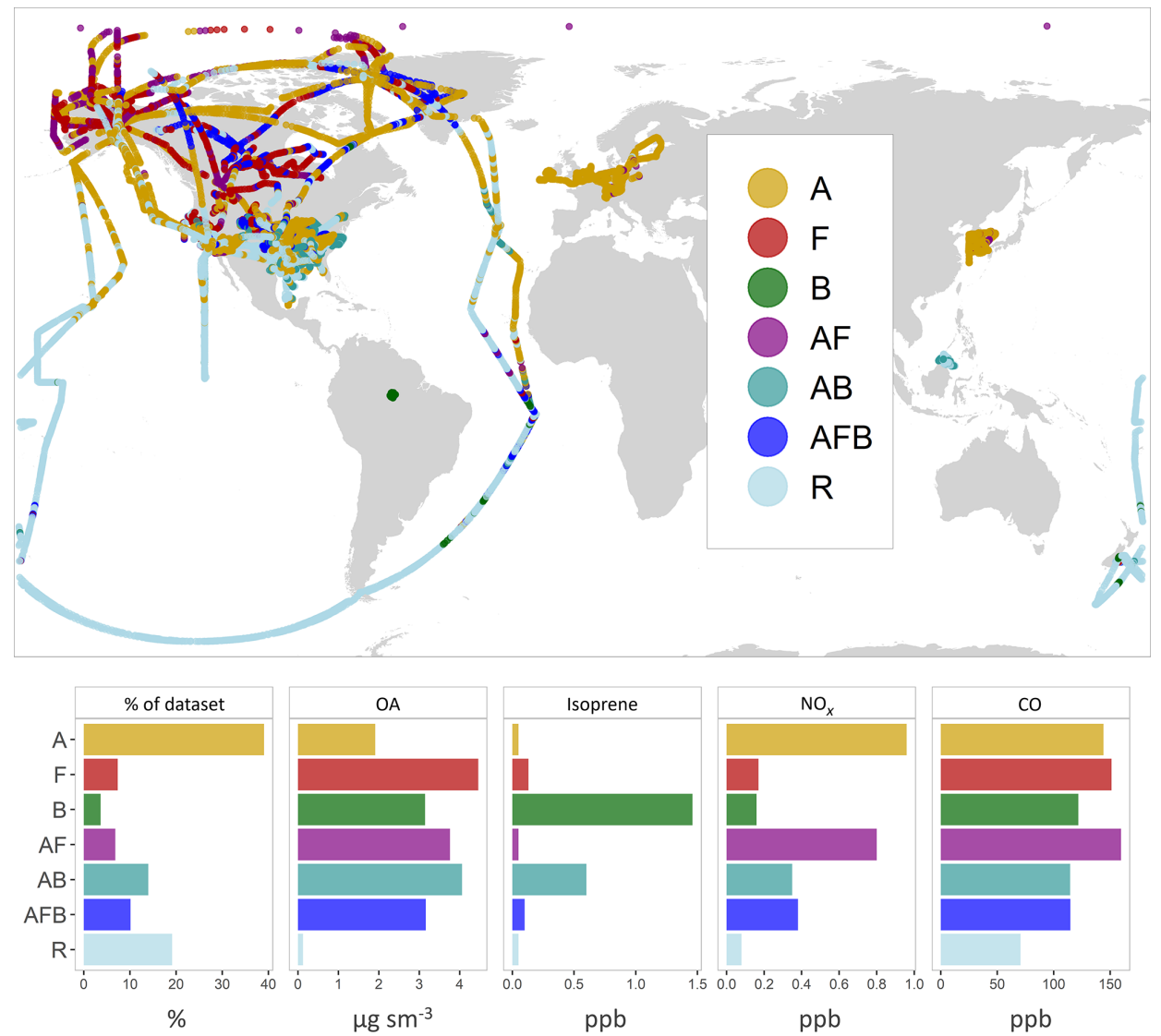

Figure 5. Flight tracks colored by regime type (top). The bar plots (bottom) compare observed mean values for various species across the different regimes. Mean values for OA are in units of micrograms per standard meter cubed $\left(\mu \mathrm{g} \mathrm{sm}^{-3}\right)$. Mean values of isoprene, nitrogen oxides and carbon monoxide are in units of parts per billion (ppb). The regimes are as follows - anthropogenic (A), pyrogenic (F), biogenic (B), anthropogenic + pyrogenic (AF), anthropogenic + biogenic (AB), mixed (AFB) and remote-marine (R). Refer to Sect. 3 for details on model sampling and averaging. See Fig. S2 for altitude-differentiated maps.

tributes over $50 \%$ of the mass are also categorized under the remote-marine regime.

While we expect these model-based categories to adequately reflect source influences (i.e., biogenic emissions over the Amazon vs. anthropogenic emissions over Asia), the relative mass contributions simulated by the model are subject to large uncertainties in OA formation and lifetime. As noted in Sect. 3, sampling conditions over the regions can vary significantly from the model treatment (such as the sampling of the Manaus anthropogenic plume or biomass burning plumes during the "biogenic" GoAmazon campaign). Due to the coarse model resolution, the regime segmentation described above is incapable of accurately categorizing some of these data points. We therefore compare the relative concentrations of observed $\mathrm{NO}_{x}, \mathrm{CO}$ and isoprene to independently validate the segmentation approach. For instance, mean observed $\mathrm{NO}_{x}$ values over the anthropogenic regime approach $1 \mathrm{ppb}$ compared to $0.36 \mathrm{ppb}$ over the $\mathrm{AB}$ regime and $0.17 \mathrm{ppb}$ over the Biogenic regime, consistent with the expected chemical signature over these regions. Similarly, averaged isoprene observations over the biogenic regime are over 20 times greater than average measurements over the anthropogenic regime.

Median concentrations over anthropogenic regions are markedly lower than those over other sources. Fireinfluenced regions display the highest variability, consistent with the expected source profile. Table S1 provides an overview of the observational datasets used for this validation. An overview of the resulting segmentation, validation and regime categories is provided in Table S2. Figure 5 provides a spatial representation of the regime categorization for all the flight data. We note that a large proportion of the observations from the GoAmazon and OP3 campaigns are densely colocated over the Amazon and Borneo and are thus difficult to discern in the figure. We also note that the "remote" points over the southeast US represent observations in the upper troposphere and are plotted over points in the lower troposphere, making them difficult to distinguish. Figure S2 provides a spatial characterization of the different regimes differentiated by altitude for further clarity. While the regime 
analysis provides useful insight into the primary sources of $\mathrm{OA}$ over the region, the classifications are intended to be broad and do not, for instance, distinguish between fresh and aged aerosol contributions from the same source. For example, a number of points over the northern Atlantic and Pacific oceans are classified as anthropogenic because they are composed of a minimum of $70 \%$ anthropogenic OA from continental sources and are high enough in concentration to not be classified as "remote".

\subsection{Evaluation of model simulations against airborne measurements}

Here we evaluate the two model schemes against the suite of airborne observations described in Sect. 3. Despite the substantial differences described in Sect. 2.1, both schemes reproduce the broad distribution (Fig. 6a) of OA observations. While the schemes exhibit slight offsets in their peaks near the lower end of the distribution, there is no evidence of a large systematic skew compared to observations, suggesting that there is not an obvious mode of formation or loss of OA that the model fails to capture. Differences between the two model distributions are also relatively small, and both exhibit fairly comparable skill. The simple scheme is less biased than the complex scheme on average, with median OA values of 0.81 and $0.86 \mu \mathrm{g} \mathrm{sm}^{-3}$, respectively, compared to the observational median of $0.68 \mu \mathrm{g} \mathrm{sm}^{-3}$. An analysis of the model-observation distributions for the individual campaigns (see Fig. 7) demonstrates that both model schemes appear to overestimate OA mass at the low and high ends of the distribution for several campaigns (as seen in the case of KORUS, GOAMA-W and OP3), while underestimating organic aerosol loadings in the middle of the distribution, suggesting a potential mischaracterization of aerosol sources and lifetimes over these regions. This might also be the result of the coarse model resolution in regions with a high spatial variance in source strengths. Both model schemes underestimate the lowest concentrations and overestimate the highest concentrations over the ocean (ATOM1-W and ATOM2-W). However, Fig. 6a suggests that these are not pervasive issues with the OA simulation at the global scale. We note, however, that this could be due to an averaging effect. Figure $6 \mathrm{~b}$ shows the same comparison for sulfate as a benchmark for a species that is generally well simulated by the GEOS-Chem model (Fisher et al., 2011; Heald et al., 2011; Kim et al., 2015). While the comparison suggests that there continues to be further scope for improvement within the OA chemical schemes, the model simulations are approaching the skill of the sulfate simulation both in terms of bias (the sulfate simulation normalized mean bias of 0.20 is similar to the model OA bias outlined above) and captured variability (with an $R^{2}$ of 0.62 for the model sulfate scheme relative to the observations compared to an $R^{2}$ of 0.41 and 0.44 for the simple and complex OA schemes, respectively). This suggests the potential importance of other drivers of variability common to both sulfate and organic aerosol, such as emissions and transport, in controlling aerosol concentrations.

Figure 8 shows that both the complex and simple schemes exhibit substantial skill in capturing the vertical OA profile across the aggregate dataset, with a vertical $R^{2}$ of 0.97 and 0.95 across the complex and simple schemes, respectively. Despite significant differences in the treatment of OA formation and atmospheric processing (and thus the source of simulated OA), both schemes appear to have similar skill in reproducing the observed vertical profile across the individual regimes, with the exception of the remote regime (driven largely by ATOM1-W and ATOM2-W) for which both schemes struggle somewhat to reproduce the variability in the observed vertical profile (Fig. S3). This result is not surprising given the low concentrations and the potential for uncertainties in transport and chemical processing to be exacerbated in the remote regime. Overall, the schemes display similar skill at capturing the vertical variability across the different regimes, highlighting that much of this variability is likely driven by the prescribed transport and vertical mixing and is independent of the OA chemical scheme.

When compared in aggregate, the simple scheme is less biased in the lower troposphere, while the complex scheme is less biased in the upper troposphere (Figs. 8, S3). This could be due to the partitioning mechanism in the complex scheme that is able to model semi-volatile OPOA and SOA with greater sophistication using the VBS framework. There are also various regime-specific differences in model performance. For instance, the complex scheme significantly overestimates OA in the lower troposphere over fire-influenced regions, likely due to the $27 \%$ increase in primary OA emissions to account for the dynamic partitioning between gas- and aerosol-phase POA. However, both the complex and simple schemes underestimate OA loadings in the midtroposphere over these same regions. This bias may be due to fire injection from large fires into the free troposphere, particularly over boreal regions (Turquety et al., 2007), that is not captured by the model (all emissions from fires are assumed to be in the boundary layer). This shortcoming is also evident over regions influenced by both anthropogenic and fire emissions (AF Regime). Figure 8 also demonstrates that lower-tropospheric concentrations cannot be reproduced over oceans without the inclusion of a marine source of POA, although the comparisons suggest that the marine POA source may be a factor of $\sim 2$ too high. While the model appears to capture the vertical profile of OA in anthropogenic regions reasonably well (Fig. 8), there are regional differences (Fig. 9), with large model underestimates of OA in the lower troposphere over California (CalNex), the central US (DC3) and Europe (EUCAARI) as well as large overestimates over Korea and parts of the Pacific influenced by outflow from Asia (Figs. 9, S4). These differences are consistent across both the simple and complex schemes, highlighting the importance of accurate anthropogenic emission inventories. The overestimate in the Asian outflow region might 
(a)

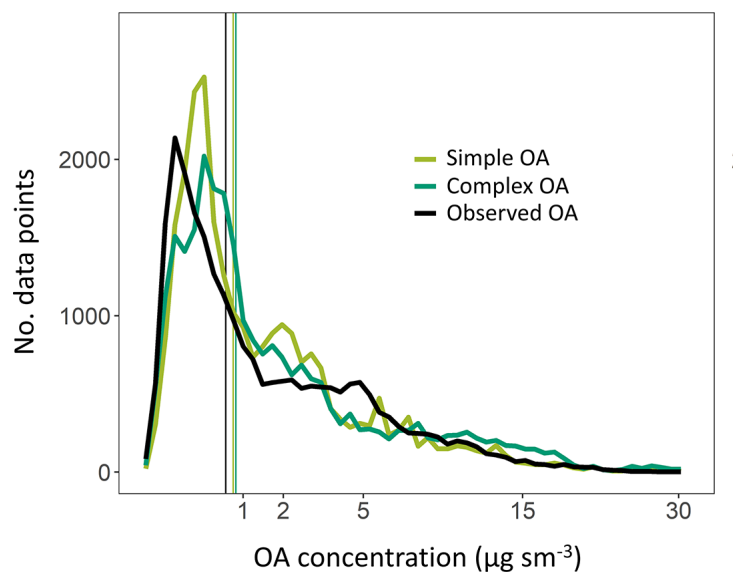

(b)

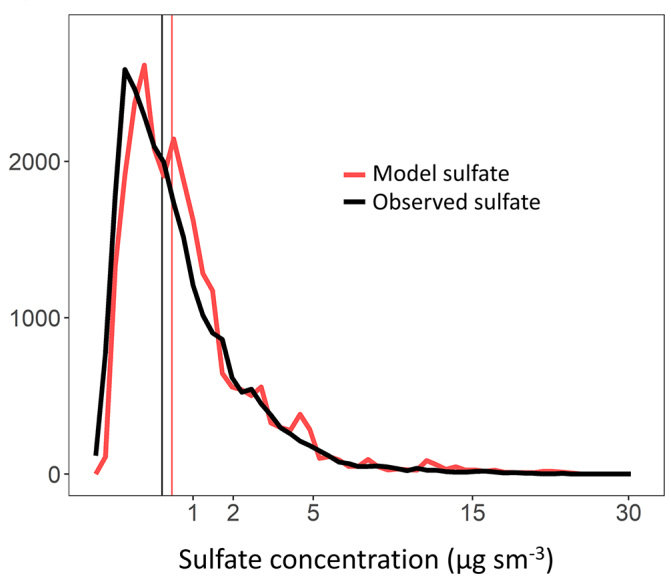

Figure 6. (a) Distribution plots of OA mass concentrations for the complex scheme (dark green), simple scheme (light green) and AMS observations (black). The $x$ axis has been transformed using a square-root function. Vertical lines represent median values for the different distributions. (b) Distribution plots of sulfate mass concentrations for the model (red) and AMS observations (black). Refer to Sect. 3 for details on model sampling and averaging.

specifically point to the importance of constraining Asian IVOC emissions, given that recent studies have suggested that SOA from IVOCs accounts for a major fraction of the total OA burden across China (Zhao et al., 2016). In regions influenced by both anthropogenic and biogenic emissions $(\mathrm{AB}$ regime) the complex scheme is less biased than the simple scheme, which underestimates the observed concentrations. This difference in bias is likely due to the more sophisticated treatment of isoprene-derived SOA yields (through the aqueous uptake and organic nitrate formation mechanisms) in the complex scheme. The $\mathrm{NO}_{x}$-dependent yields of isopreneand terpene-derived SOA in the complex scheme might also be a source of increased model skill, given that organic nitrates and oxidized isoprene products account for a dominant fraction of the total modeled OA in the complex scheme over these regions. The relative skill of the complex scheme is unsurprising given that the vast majority of the $\mathrm{AB}$ regime is over the southeast US, for which the complex scheme was developed and validated. However, the model skill over the $\mathrm{AB}$ regime may be fortuitous, given that recent studies have demonstrated that a significant fraction of the observed OA over the southeast US is generated from monoterpene precursors rather than isoprene (Xu et al., 2018; Zhang et al., 2018). This potentially suggests that monoterpene SOA yields over the southeast US are low in the model. This may also contribute to the underestimate of OA observed during EUCAARI, which is influenced by the forests of northern Europe (Figs. 9, S4). Recent work has also demonstrated that organo-nitrates contribute a significant fraction of the total OA mass over certain parts of Europe (Kiendler-Scharr et al., 2016), potentially indicating a model underestimate in organo-nitrate formation over the region. In contrast to its skill over the US, the complex scheme displays a large posi- tive bias over biogenic (B) regions (such as the Amazon), primarily driven by an overestimate in terpene SOA, potentially suggesting that the scheme may not accurately capture global biogenic SOA burdens and needs to be better constrained. The overestimate of OA in both schemes in the boundary layer over the Amazon and Borneo is accompanied by an underestimate in the upper troposphere (Fig. 9), potentially indicating overly rapid model SOA formation or a failure to capture vertical mixing in the region.

We note that while the observations used in this study have a large spatial range, they are temporally limited and might not be representative of the mean state. Atypical meteorological conditions during the different campaigns may contribute significantly to the model-observation bias. For example, the EUCAARI campaign was characterized by a westward flow across Germany and the southern UK (Morgan et al., 2010), capped by a strong inversion that limited vertical mixing. Similarly, differences in sampling priorities might impact the chemical composition of the observations in a manner that deviates from climatology. For instance, the GoAmazon campaign was partially oriented toward sampling anthropogenic outflow from the city of Manaus (Shilling et al., 2018), impacting the OA measurements in a manner that the model is ill-equipped to reproduce. However, despite the various gaps in model fidelity, this analysis suggests that both schemes are relatively skilled at capturing the observed magnitude and vertical variability across the different regimes. A previous comparison of observed vertical profiles by Heald et al. (2011) concluded that the two-product SOA with non-volatile POA model used in earlier versions of GEOS-Chem required additional sinks and sources in order to match observations, suggesting the need for photochemical sinks from photolysis and fragmentation 

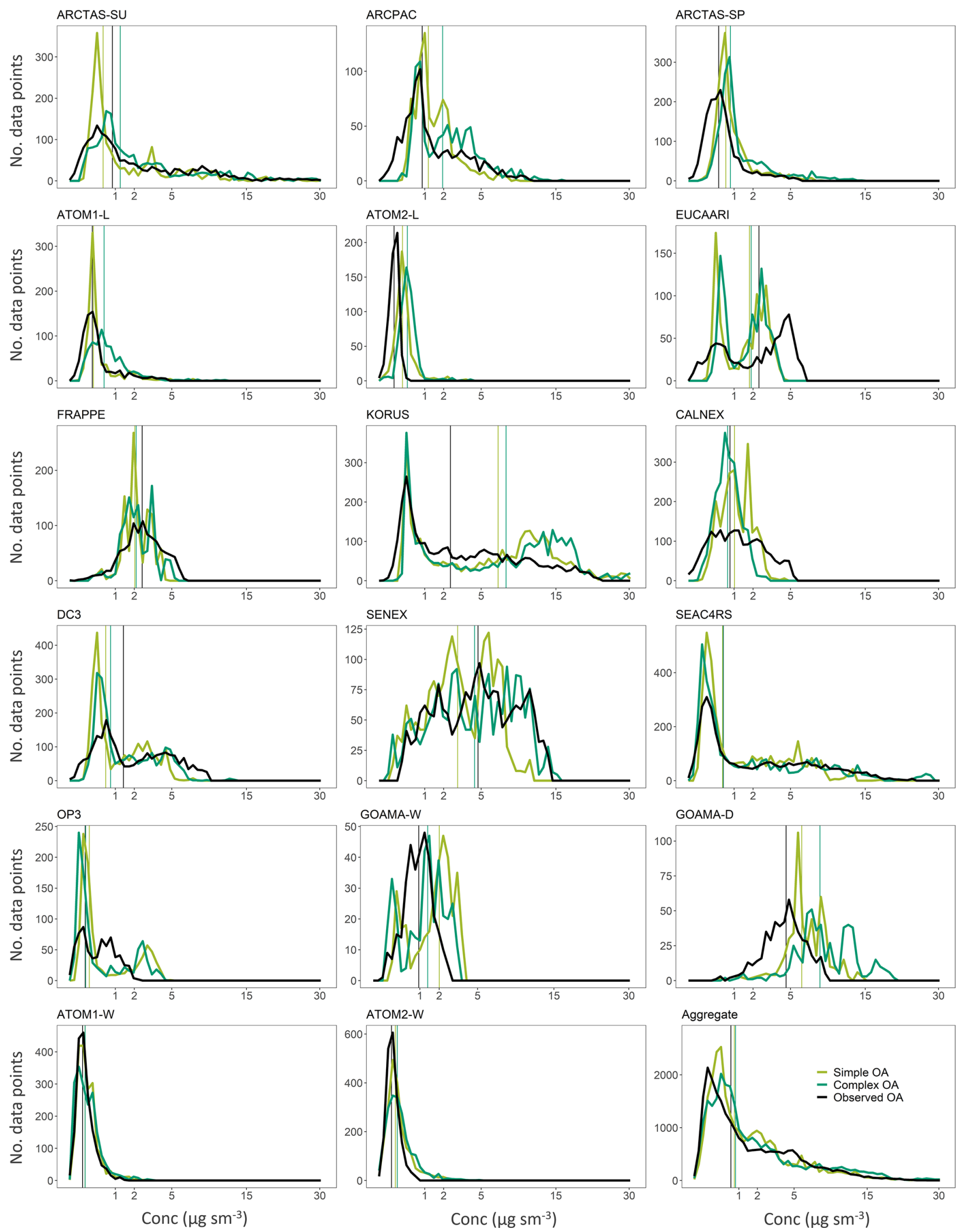

Figure 7. Superimposed distributions from the complex (dark green) and simple (light green) schemes with the observations in black for the different campaigns. Vertical lines represent median values for the different distributions. 

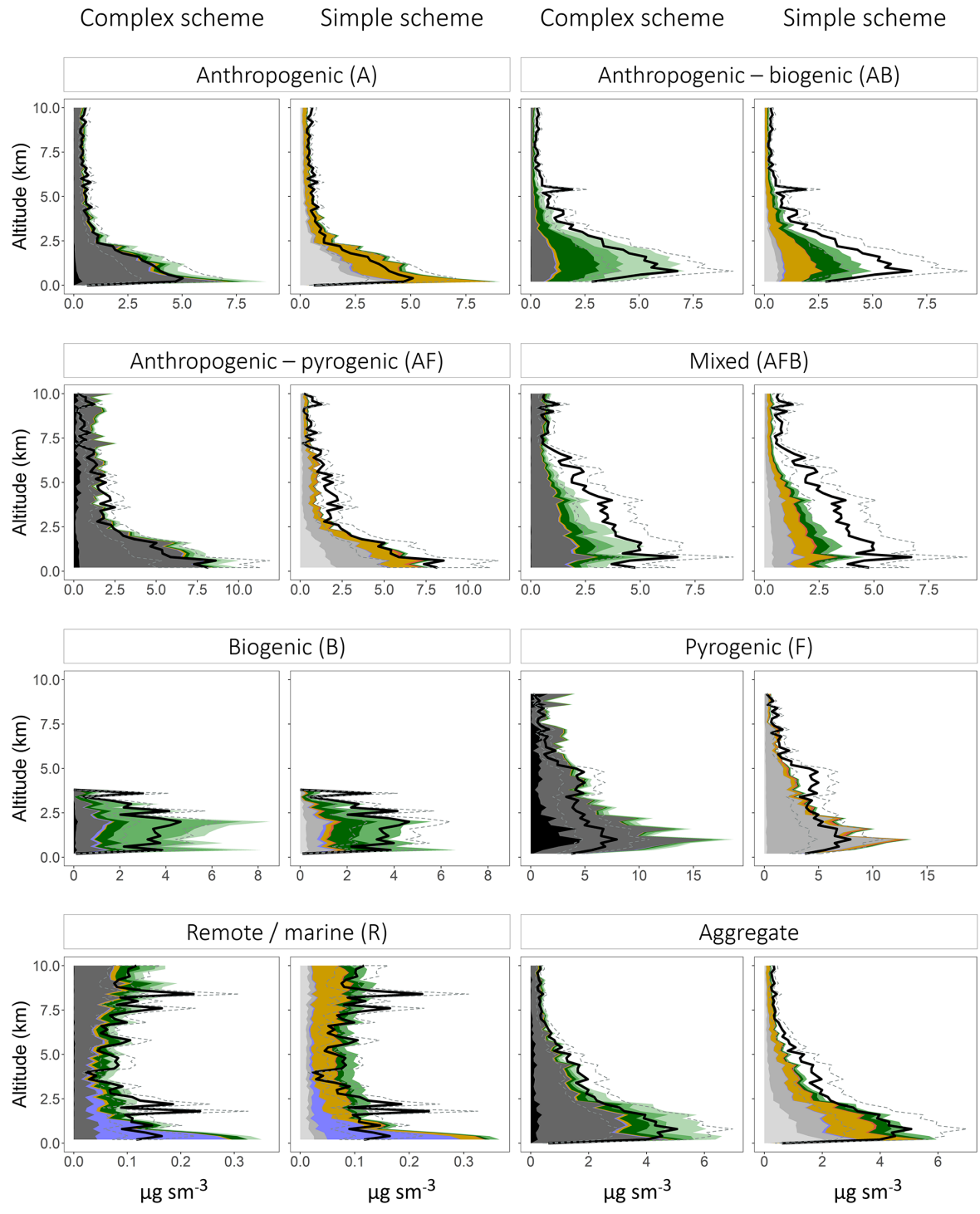

\begin{tabular}{|c|c|c|c|c|c|c|c|}
\hline \multicolumn{4}{|c|}{ Complex scheme } & \multicolumn{4}{|c|}{ Simple scheme } \\
\hline EPOA & MPOA & ISOA & OrgNit & A - POA & MPOA & FSOA & TSOA \\
\hline OPOA & ASOA & TSOA & & $\mathrm{F}-\mathrm{POA}$ & ASOA & ISOA & \\
\hline
\end{tabular}

Figure 8. Mean vertical profiles (in kilometers) comparing the observed (black) and simulated (colored) OA mass concentrations classified into the different regimes. The dashed lines represent the uncertainty in the observed OA mass loadings. The profiles are binned at $200 \mathrm{~m}$ intervals. For the simple scheme, A-POA represents anthropogenic POA and F-POA represents pyrogenic POA. Refer to the text for other OA categories and details on model sampling.

pathways. Figure 8 indicates no obvious need for large additional sinks for either scheme in aggregate, although specific regions may benefit from a more sophisticated treatment of SOA formation and loss.

An analysis of the coefficients of determination $\left(R^{2}\right)$ and the normalized mean biases (NMB) across the different regimes (Fig. 10) and campaigns (Fig. 11) indicates that the complex scheme marginally outperforms the simple scheme across the aggregate dataset in its ability to reproduce the ob- served OA variability (with an $R^{2}$ of 0.44 compared to an $R^{2}$ of 0.41 for the simple scheme), with small differences in performance over the different regimes. The simple scheme is more skilled at minimizing bias over the aggregate dataset and most source regimes, but it is biased low over the $A B$ and AFB regimes. Figure $\mathrm{S} 4$ provides spatial context for the model-measurement comparisons discussed here. The result that both the complex and simple schemes slightly overestimate $\mathrm{OA}$ in the aggregate dataset is distinct from the conclu- 


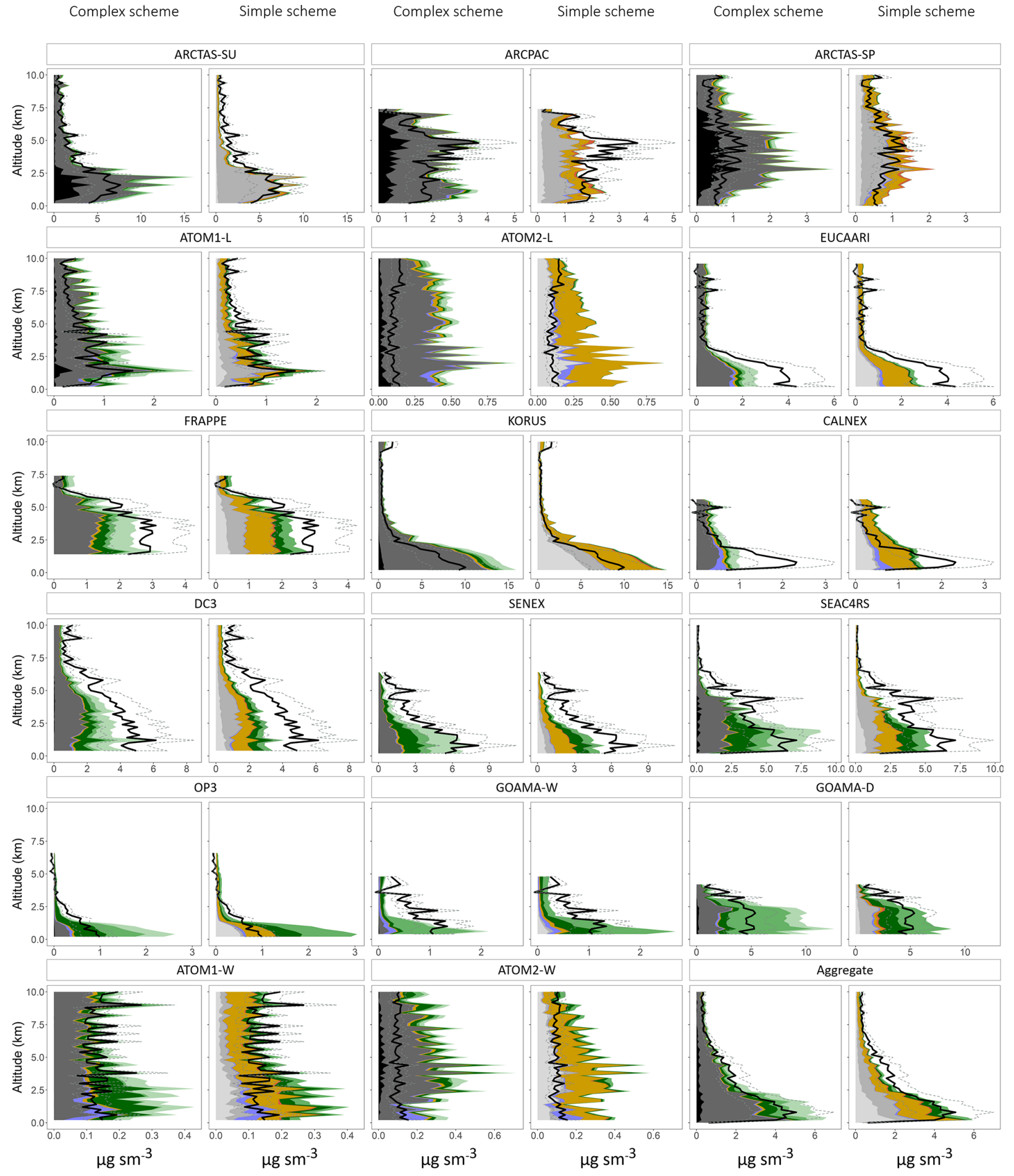

Complex scheme

Simple scheme

\begin{tabular}{lllllllll}
\hline EPOA & MPOA & ISOA & OrgNit & A-POA & MPOA & FSOA & TSOA & Obs \\
OPOA & ASOA & TSOA & & F-POA & ASOA & ISOA &
\end{tabular}

Figure 9. Mean vertical profiles (in kilometers) comparing the observed (black) and simulated (colored) OA mass concentrations across the different campaigns. The dashed lines represent the uncertainty in the observed OA mass loadings. The profiles are binned at $200 \mathrm{~m}$ intervals. For the simple scheme, A-POA represents anthropogenic POA and F-POA represents pyrogenic POA. Refer to the text for other OA categories and details on model sampling. 
(a)

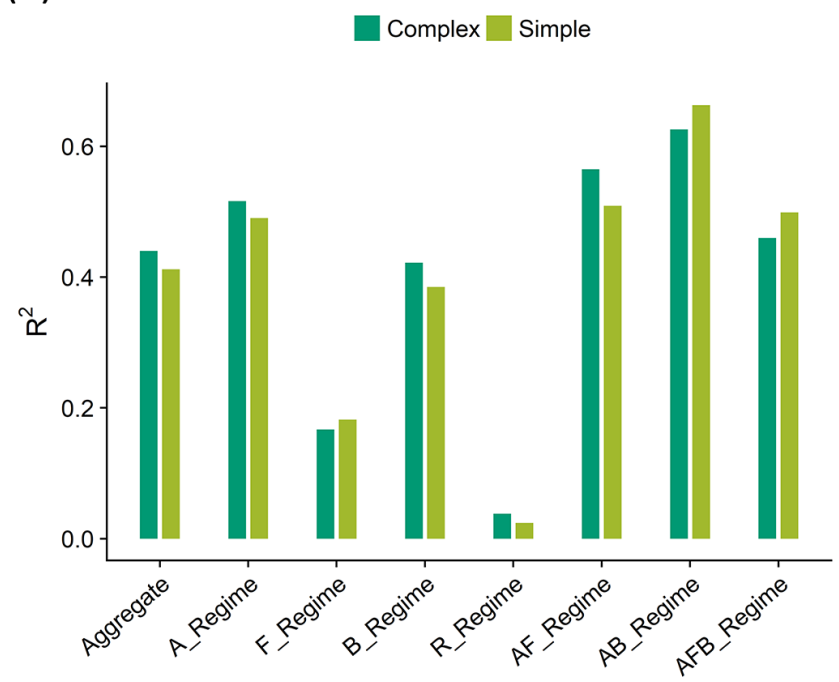

(b)

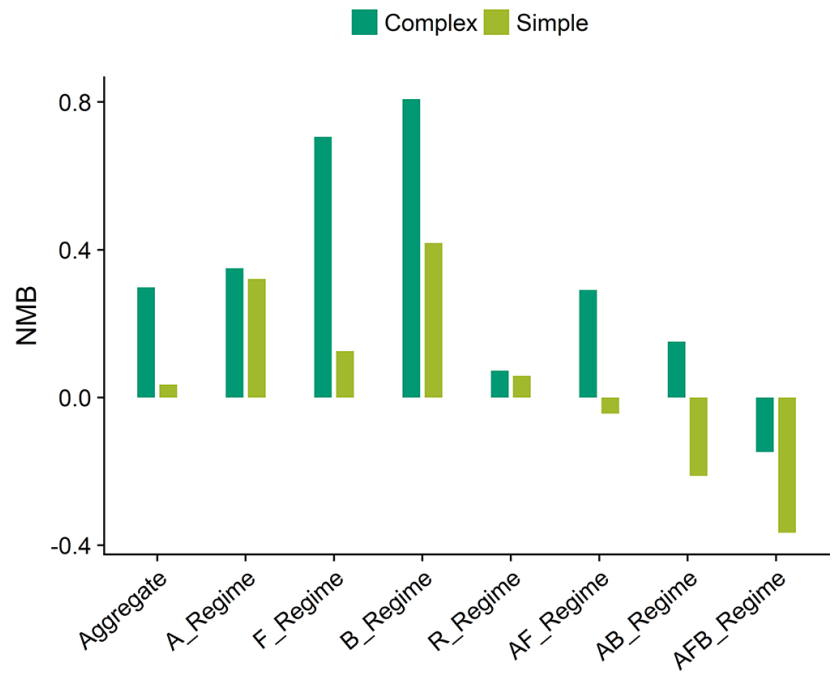

Figure 10. Statistical evaluation of the OA model skill for the complex (dark green) and simple (light green) scheme against observations shown as (a) the coefficients of determination $\left(R^{2}\right)$ and (b) the normalized mean bias (NMB) across the segmented regimes. A positive normalized mean bias indicates that the model overpredicts OA loadings.

(a)

Complex $\square$ Simple $\square$ Sulfate

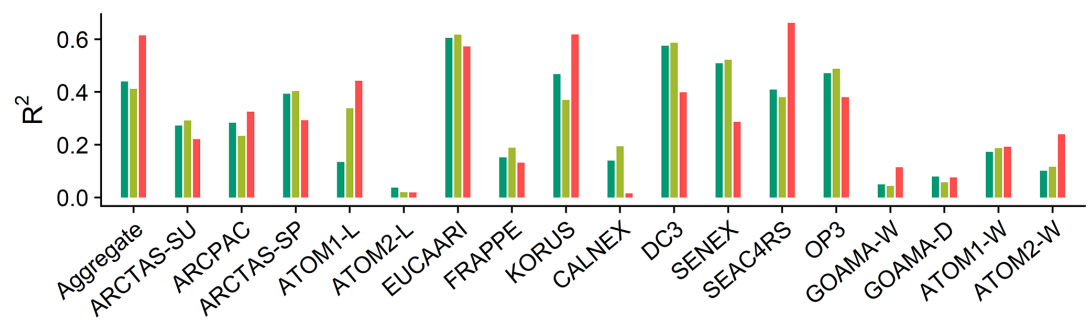

(b)

Complex $\square$ Simple $\square$ Sulfate

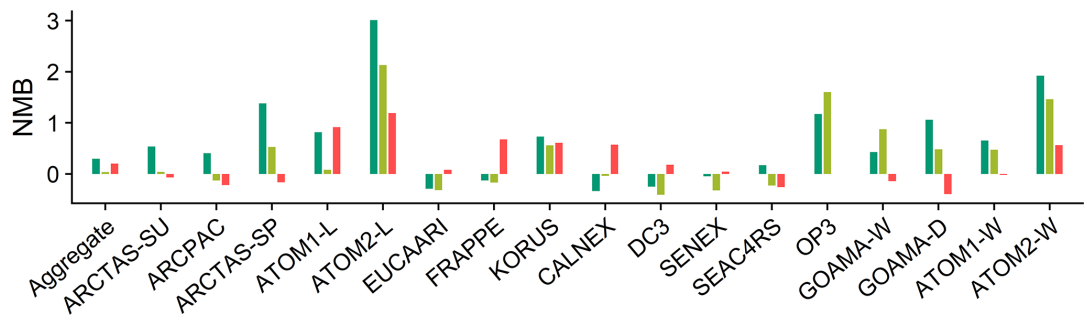

Figure 11. Statistical evaluation of the model skill against observations shown as (a) the coefficients of determination $\left(R^{2}\right)$ and (b) the normalized mean bias (NMB) across the individual field campaigns. The complex (dark green) and simple (light green) OA schemes are compared to the sulfate simulation (red).

sion drawn by Heald et al. (2011), who demonstrated a consistent model underestimate of OA over most regions. In this study, median modeled concentrations are within $1 \mu \mathrm{g} \mathrm{sm}^{-3}$ of the observations for 14 out of the 17 datasets analyzed with both schemes. Figure S5 provides distributions of the ratio and bias between the observed and modeled organic aerosol concentrations for both model schemes across the different campaigns.

When compared to the simple scheme, the complex scheme does a superior job at minimizing the bias over much of the US. However, there continues to be an underestimate in OA loadings in both schemes (Figs. 9, S4). The bias is likely driven by a variety of factors that need to be explored 
on a regional basis. For instance, a previous model analysis of FRAPPE observations over Colorado suggested that an underestimate of anthropogenic emissions from the oil and gas sector contributed to an underestimate of ASOA in the region (Bahreini et al., 2018). Both schemes overestimate OA loadings in the northern latitudes (over parts of Alaska and Canada), likely due to an overestimate in POA from fires (Figs. 9, 11, S3, S4). The complex scheme is also biased high over the Amazon rainforest due to the large mass loadings of terpene SOA and various isoprene- and monoterpene-derived organo-nitrates. Conversely, the simple scheme assumes an identical SOA yield from both monoterpenes and sesquiterpenes, likely degrading its skill. Both schemes are biased low over Europe but high over the Korean Peninsula, which are both anthropogenically influenced regions, potentially due to the different regional inventories (EMEP and MIX) used by the model. Both schemes overestimate the OA concentrations observed during the winter ATom-2 deployment (Figs. 9, 11) driven largely by an overestimate in anthropogenic OA, particularly in the North Pacific (Fig. S4); a similar bias is not apparent in the summertime ATom-1 deployment, suggesting a potential seasonal overestimate in anthropogenic emissions in Asia that may warrant further study. In comparison to the complex scheme, simulations conducted using a pure-VBS treatment of SOA were significantly less skilled at capturing OA variability and minimizing model bias over the aggregate dataset, demonstrating the value of an explicit description of isoprene SOA over the nonmechanistic VBS treatment.

\subsection{Exploring the model-measurement differences in OA}

There are many factors that contribute to the model performance over individual campaigns or regions, and investigating the specific drivers of regional differences is not the goal of this work. However, here we explore general features of the model-measurement comparisons to identify issues that may inform the development of future model OA schemes.

There is a large spread in the model-observation bias both within and across the individual campaigns. A comparison of OA metrics (such as $R^{2}$ and NMB) with the corresponding model sulfate simulations for the same campaigns demonstrates a similar variance (Fig. 11). This suggests that the lack of model skill over certain campaigns could be due to physical processes, such as transport and deposition, that impact both OA and sulfate species and are independent of the chemical scheme utilized.

A comparison between the simulated and observed coefficients of variation $(\mathrm{CV}$; defined as the ratio of the standard deviation to the mean) for the different campaigns indicates that both the complex and simple schemes are relatively skilled at capturing the range of observations within the individual campaigns, with the $\mathrm{CV}$ from the simple scheme and the complex scheme both showing a high degree of correlation when compared to the observed CV ( $R^{2}$ of $0.7 ;$ Fig. 12).

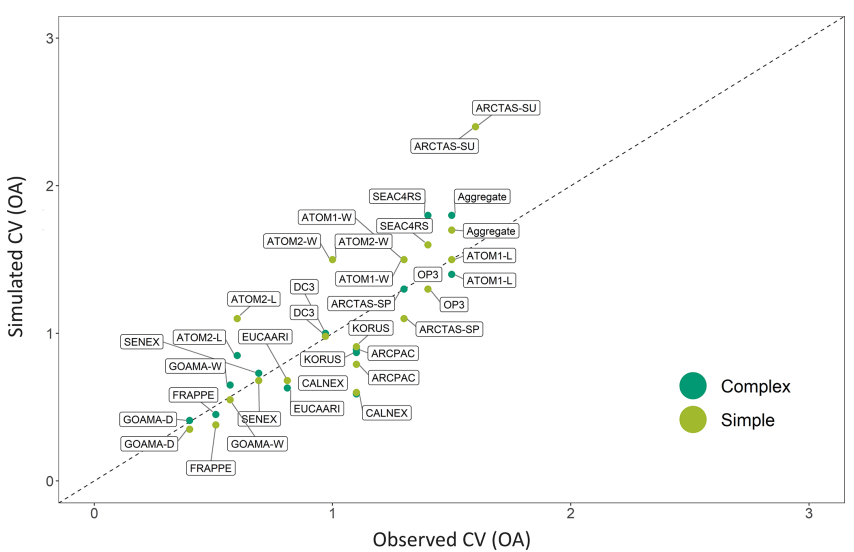

Figure 12. A comparison of the simulated (GEOS-Chem) coefficient of variation $(\mathrm{CV}$, the ratio of the standard deviation to the mean) for the complex (dark green) and simple (light green) OA schemes against the observed $\mathrm{CV}$ for each airborne campaign. The one-to-one line is shown as a dashed black line.

The CV provides a measure of statistical dispersion. Figure 12 highlights how localized campaigns such as GoAmazon and FRAPPE have low CVs. Both schemes demonstrate a lack of ability to accurately capture intra-campaign variability (described above by the campaign $R^{2}$ in Fig. 11). The coarse model resolution and the resulting inability to resolve sub-grid concentration and emission gradients is likely an important barrier to model skill, particularly across more localized campaigns (with low CVs) with smaller dynamic ranges and/or spatial extents, like OP3, KORUS-AQ and FRAPPE. To explore this, additional simulations (not shown) were conducted using a nested $0.5^{\circ} \times 0.625^{\circ}$ grid with the simple scheme (while maintaining all other model parameters) over North America for the FRAPPE campaign and over Asia for the KORUS-AQ and OP3 campaigns. The nested simulations performed significantly better at capturing the observed variability in OA for FRAPPE (with a change in $R^{2}$ from 0.19 to 0.34 ). However, the nested KORUS-AQ simulations resulted in a decrease in model skill, with a change in $R^{2}$ from 0.37 to 0.25 . This result suggests that uncertainties in emission inventories and meteorology over Asia may degrade higher-resolution comparisons, consistent with recent work demonstrating deficiencies in emission inventories in the region (Goldberg et al., 2019). The nested simulations also did nothing to improve model fidelity for the OP3 campaign over Borneo (with a change in $R^{2}$ from 0.49 to 0.48). Biogenic emissions and chemical conditions are likely relatively uniform over this region, and therefore a higherresolution simulation does not lead to a distinct improvement in the simulation.

To compare the underlying source signatures for the ambient $\mathrm{OA}$ concentrations over different regimes, we analyze the relationship between $\mathrm{OA}$ and $\mathrm{CO}$ concentrations across both the model schemes and the observational dataset (Fig. S6). 
Generally, the model underestimates the observed OA : CO slope but captures the relative difference in $\mathrm{OA}: \mathrm{CO}$ slopes observed in different environments. The two schemes are broadly consistent, and the model skill in reproducing this relationship is not notably better or worse over most regimes or environments, providing little insight into model scheme deficiencies. However, there is a notable difference between the observed and modeled OA:CO slope over the anthropogenic regime (though it is not consistent over all regions), potentially warranting further exploration of regional anthropogenic OA yields within the simple scheme.

Model bias is also evaluated as a function of a suite of observed parameters (relative humidity, temperature $\mathrm{NO}_{x}$, sulfate, isoprene, $\mathrm{CO}$ ) to identify any salient relationships (Fig. S7). We find that the model-observation bias in the complex scheme displays a robust positive correlation with the observed relative humidity and sulfate concentrations (Fig. 13). This suggests that the aqueous uptake of isoprene oxidation products in the complex scheme is overestimated in conditions of high humidity and high acidity and that further work is needed to constrain this formation pathway under a range of ambient environmental conditions. It also suggests that large additional pathways of aqueous SOA formation are unlikely to be missing from the model. In-cloud processing of SOA is not explicitly considered in the complex scheme, with Marais et al. (2016) estimating that the pathway accounts for a minor fraction of the total SOA. However, studies have suggested that cloud chemistry can significantly impact SOA concentrations during certain cloudcycling events (Brégonzio-Rozier et al., 2016; Giorio et al., 2017), indicating the need for more research to constrain the regional relevance of such systems.

The simple and complex schemes differ significantly in their treatment of primary organic aerosol. The simple scheme simulates POA using two non-volatile primary species, while the complex scheme uses two semi-volatile primary species that partition between the gas and aerosol phase. This is an important difference because aerosol partitioning in the semi-volatile species is sensitive to ambient temperature and organic aerosol concentration, influencing concentrations far away from the original source. Given the differences in POA treatment, an analysis of model skill (in terms of its ability to minimize bias and capture observational variability) was conducted by considering the effects of combining EPOA and OPOA loadings from the complex scheme with SOA loadings from the simple scheme (and vice versa). With an $R^{2}$ of 0.46 and an NMB of 0.03 , this model configuration (complex scheme POA with simple scheme SOA) outperformed both the simple and complex schemes over the aggregate dataset in its ability to capture the observed variability and minimize observational bias, supporting the need to explicitly model the semi-volatile nature of POA (Fig. S8). We note that this analysis assumes a parameterized enthalpy of vaporization of $50 \mathrm{~kJ} \mathrm{~mol}^{-1}$ to estimate saturation vapor pressures for semi-volatile partitioning in the complex scheme, an assumption that needs to be more rigorously examined in field and modeling studies.

Based on the results from the simple scheme, an offline analysis was conducted to optimize the various model parameters by running a multivariate linear regression in combination with a gradient descent optimizer that used a weighted cost function to maximize the coefficient of determination and minimize the normalized mean bias. This was done across multiple parameter classes (such as emission rates and yields) in order to ascertain a set of optimized model parameters. The optimized parameters improved the model coefficient of determination by only up to $5 \%$ in most cases. This is perhaps unsurprising given that this simplistic analysis assumes that simulated OA concentrations are linearly correlated with changes in emissions and yields, an assumption that is not truly representative of the model treatment, which includes nonlinear effects such as wet deposition loss. More work is required to optimize these parameter classes using an online analysis.

We also incorporated a rudimentary $\mathrm{NO}_{x}$ and sulfate dependency into the biogenic SOA yields for the simple scheme using offline monthly averaged $\mathrm{NO}_{x}$ and sulfate concentrations from a full-chemistry GEOS-Chem simulation for the year 2013. Isoprene-derived SOA was modeled as having a negative $\mathrm{NO}_{x}$ dependency, ranging from a $3 \%$ yield in low$\mathrm{NO}_{x}$ conditions to a $2.25 \%$ yield at high $\mathrm{NO}_{x}$. Monoterpene SOA was also modeled as having a negative $\mathrm{NO}_{x}$ dependency - ranging from a $10 \%$ yield under low- $\mathrm{NO}_{x}$ conditions to a $7.5 \%$ yield under high- $\mathrm{NO}_{x}$ conditions. Sesquiterpene SOA yields were simulated as having a positive $\mathrm{NO}_{x}$ dependence, ranging from $10 \%$ under low- $\mathrm{NO}_{x}$ conditions to $20 \%$ under high- $\mathrm{NO}_{x}$ conditions. These yields were determined based on an analysis of relevant literature (e.g., Kroll et al., 2006; $\mathrm{Ng}$ et al., 2007) coupled with various offline optimizations from this study. ISOA was also modeled as having a positive $\mathrm{SO}_{4}$ dependence (from a yield of $1.5 \%$ in clean conditions to a high of $4.5 \%$ in extremely polluted conditions with high sulfate) based on previous work (Marais et al., 2016) that demonstrated the importance of the acid-catalyzed SOA formation pathway for isoprene.

The $\mathrm{NO}_{x}$-dependent parameterization did not meaningfully improve model skill. However, the sulfate parametrization improved model performance by a few percentage points, bringing the aggregate $R^{2}$ to within 0.01 of the complex scheme and demonstrating the potential to further improve model performance. The analysis also points to the limitations of the simple scheme in its current form. For instance, OA yields have also been shown to be highly variable by region and source, particularly in the case of fires (Jolleys et al., 2014), a facet that is not currently captured within the simple scheme. Chemical processing lifetimes are also highly dependent on the ambient regime, with observational studies finding that OA in urban environments (e.g., Jimenez et al., 2009) is often oxidized at timescales that are significantly faster than the $1.15 \mathrm{~d}$ assumed in the simple 
(a)

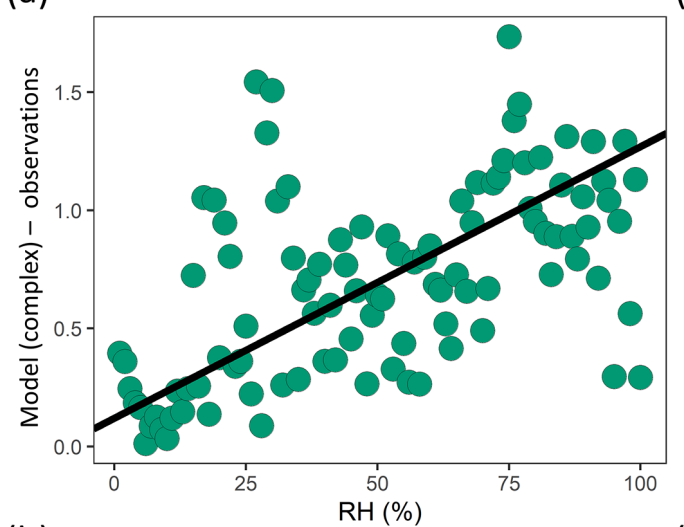

(b)

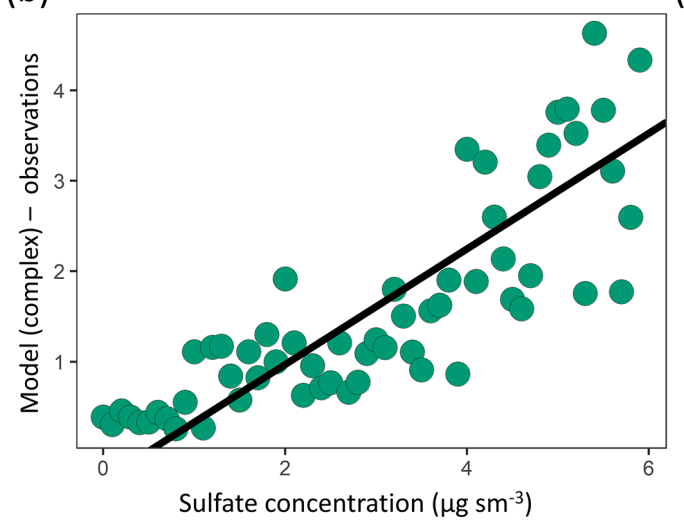

(c)

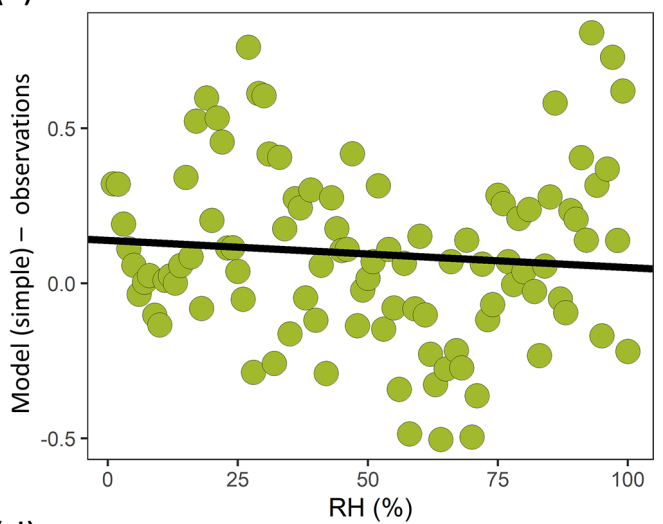

(d)

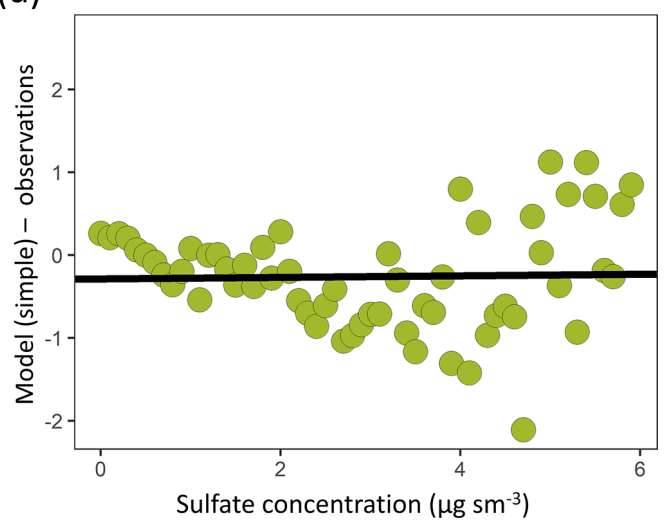

Figure 13. A comparison of model-observation OA bias and observed $(\mathbf{a}, \mathbf{c})$ relative humidity and $(\mathbf{b}, \mathbf{d})$ sulfate mass concentrations for the complex (a, $\mathbf{b}$ - dark green) and simple (c, $\mathbf{d}$ - light green) OA schemes across the aggregate dataset (observations are binned by intervals of $1 \%$ for RH and $0.1 \mu \mathrm{g} \mathrm{sm}^{-3}$ for sulfate). The best-fit line is shown in black.

scheme. Our rudimentary optimization of the simple scheme with a sulfate dependency demonstrates the potential to further improve model performance, although additional work is needed to conduct a more rigorous optimization of the various model parameters.

\section{Conclusions}

In this study, we use a suite of observations that represent a variety of spatial and chemical regimes to undertake a comprehensive evaluation of the two standard organic aerosol schemes in the GEOS-Chem chemical transport model, both with very different treatments of OA. The simple scheme, which uses non-volatile tracers to model primary organic aerosol, simulates a total annual POA burden that is approximately two-thirds of the comparable burden simulated by the complex scheme that treats POA as semi-volatile. While the total SOA burdens are similar, the simple scheme simulates an anthropogenic SOA burden that is over 6 times greater than the complex scheme. Conversely, the complex scheme simulates a global burden of biogenic SOA that is roughly 2.5 times greater than the comparable burden in the sim- ple scheme, largely due to higher isoprene SOA and organonitrate mass loadings. Due to the lack of well-differentiated fossil fuel and biofuel emissions, the simple parameterization likely overestimates ASOA from biofuel sources. We note that the simple ASOA parameterization as applied in this study might also capture some "anthropogenically controlled" SOA formed from biogenic VOC precursors, potentially accounting for some of the disparities noted above. More work is needed to constrain these yields across different chemical regimes at a global scale.

Despite the substantial difference in the complexity of these OA schemes and the relative magnitudes of their sources, differences in their ability to capture observed airborne OA concentrations from around the world are modest. The simple scheme appears to slightly outperform the more sophisticated complex scheme in terms of its ability to minimize bias over the aggregate dataset, while the complex scheme is slightly more skilled in its ability to capture the observed variability. When compared spatially to the simple scheme, the complex treatment is less biased over the southeast US and certain regions in North America and Europe, while displaying reduced skill in pyrogenic regimes over the northern latitudes and biogenic regimes in the Ama- 
zon, where it produces large overestimates. When comparing vertical profiles, both schemes overestimate OA loadings in the lower troposphere. However, the complex scheme is more skilled at capturing the mid-tropospheric burden, likely due to the more sophisticated semi-volatile treatment of primary OA. Both schemes underestimate mid-tropospheric OA loadings over fire-influenced campaigns, pointing to the potential importance of fire injection into the free troposphere in those regions, which was not modeled in this study. The overestimate of OA in the tropical boundary layer and the underestimate aloft similarly indicate model failure to capture the chemical lifetimes of biogenic SOA formation or point to deficiencies in its ability to capture vertical mixing in these regions. Our analysis of nested simulations over North America and Asia also points to the importance of constraining regional emissions and local meteorology over Asia in order to improve model fidelity. As a result of our analysis, we recommend that (1) POA be modeled as semi-volatile, (2) fire POA emissions not be scaled up by $27 \%$ in the complex scheme and (3) marine POA be included in the simulation of marine-influenced regions. Further explorations of the fire injection heights of aerosols (e.g., Zhu et al., 2018) and anthropogenic emissions of OA precursors, particularly in Asia, are needed. However, despite these deficiencies, both model schemes generally capture the magnitude of the observed OA. This is particularly true given the $38 \%$ uncertainty associated with the AMS OA observations; $33 \%$ of the modeled data points fall within this observed uncertainty, demonstrating significant progress since the first airborne analysis of $\mathrm{OA}$ simulated in the GEOS-Chem model, which revealed biases of up to an order of magnitude (Heald et al., 2005).

The surprising result that both the simple and complex schemes perform comparably across the aggregate dataset challenges our expectations that a more complex and mechanistic description of OA should outperform a highly parameterized scheme. This may suggest that accurately capturing the source influence (i.e., emissions of OA and its precursors) is a more crucial limitation on current model skill than the specific details pertaining to OA formation. Alternatively, it may suggest that substantial deficiencies remain in our understanding of the mechanistic formation of OA, as represented in the complex scheme (for example, associated with the oxidation of aromatics). The VBS oxidation of monoterpenes and sesquiterpenes in the complex scheme uses $\mathrm{NO}_{x}$-dependent yields to determine the formation of second-generation oxidation products. However, these yields are uncertain and recent studies have suggested the importance of accounting for interactions between multigenerational oxidation products when determining these yields, demonstrating that such interactions can significantly depress SOA formation under ambient conditions (McFiggans et al., 2019). Recent work has also demonstrated the importance of $\mathrm{RO}_{2}$ autoxidation pathways in the formation of SOA (e.g., Crounse et al., 2013; D'Ambro et al., 2017; Pye et al., 2019). A more sophisticated, explicit treatment that accounts for these oxidation product interactions under different chemical regimes could thus improve model fidelity (but with an associated computational cost). Additionally, the underlying mechanisms (and related uptake coefficients) behind the treatment of isoprene in the complex scheme were developed and validated primarily using data from campaigns over the southeast US; more work is needed to constrain these coefficients under different chemical regimes outside this region. Finally, the lack of model fidelity could also indicate the importance of better constraining the physical processes inherent to both schemes, such as transport and deposition, or point to the salience of photochemical loss, atmospheric aging and fragmentation loss, which are not represented in either scheme (Heald et al., 2011; Hodzic et al., 2016). In addition to these factors, the observational comparison with model sulfate suggests that the large drivers of unexplained model variability might be exogenous to the $\mathrm{OA}$ chemical scheme.

At the global scale, the computational advantages and relative skill of the simple scheme make it an attractive tool. Our analysis demonstrates that this computational benefit is accompanied by a relatively limited decline in model skill. However, caution should be exercised when applying such a scheme that fails to incorporate the mechanistic responses necessary to ensure predictive skill (e.g., for climate studies). There is thus a need to improve upon both the simple parameterized approach as well as the more sophisticated mechanistic scheme in order to further our understanding of organic aerosol in the atmosphere.

This study highlights the critical need to develop new methods to translate experimental studies on the formation and fate of OA into global models in order to identify the key processes that are required to reproduce observed atmospheric OA concentrations. The study also indicates the importance of additional observational constraints to benchmark and improve model fidelity. The AMS observations offer a rich mass-differentiated dataset that could be further leveraged using factor ratios and clustering analyses to inform future model evaluations. Standardized reporting of AMS data during future campaigns could enable further model evaluation using a more comprehensive range of the instrument's capabilities. In addition, observations of organic aerosol would be particularly useful in understudied regions such as India, China, central Asia and Africa. Recent campaigns over these regions (such as the 2016 DACCIWA, 2018 ORACLES and 2016 SWAAMI campaigns) could also be leveraged to study the relevant chemistry. Due to the relative paucity of airborne AMS observations, this study does not include an analysis of seasonal trends. Additional aircraft campaigns over the fall and winter seasons (such as the 2015 WINTER campaign over the northeastern US) could enable a more comprehensive intra-annual analysis, which could provide insight into seasonal sources. There is also a need for more field observations at a regional scale, as opposed to localized sampling, in order to better constrain and improve 
the treatment of organic aerosol in large-scale regional and global models. Finally, this analysis, while a comprehensive model evaluation of OA, is limited to two schemes within one model and does not include any surface constraints. An ongoing, meticulous evaluation of new OA model schemes against globally distributed datasets is thus paramount to advancing simulations of the air quality and climate impacts of aerosols.

Code and data availability. The GEOS-Chem model code is available at http://acmg.seas.harvard.edu/geos/ (last access: 5 January 2019; International GEOS-Chem User Community, 2018). Observational data for ARCTAS (https://doi.org/10.5067/ SUBORBITAL/ARCTAS2008/DATA001; Chen, 2020), ATom (https://doi.org/10.3334/ORNLDAAC/1581; Wofsy et al., 2018), DC3 (https://doi.org/10.5067/AIRCRAFT/DC3/DC8/AEROSOLTRACEGAS; DC3 Science Team, 2012), FRAPPE (https://www-air.larc.nasa.gov/cgi-bin/ArcView/discover-aq. co-2014?C130=1; FRAPPE Science Team, 2014), KORUS-AQ (https://doi.org/10.5067/SUBORBITAL/KORUSAQ/DATA01; Chen, 2018) and SEAC4RS (https://doi.org/10.5067/AIRCRAFT/ SEAC4RS/AEROSOL-TRACEGAS-CLOUD; SEAC4RS Science Team, 2014) can be obtained from the NASA LaRC data archive. GoAmazon data are accessible through the Atmospheric Radiation Measurement (ARM) user facility (https://www.arm.gov/research/campaigns/amf2014goamazon;

GoAmazon Science Team, 2014). Data for the OP3 (http://data.ceda.ac.uk/badc/op3; OP3 Science Team, 2008) and EUCAARI (http://data.ceda.ac.uk/badc/appraise/data/adient; EUCAARI Science Team, 2008) campaigns are archived at the Centre for Environmental Data Analysis (CEDA). ARCPAC (https://esrl.noaa.gov/csd/groups/csd7/measurements/ 2008ARCPAC/P3/DataDownload/; ARCPAC Science Team, 2008), CalNex (https://esrl.noaa.gov/csd/groups/csd7/measurements/ 2010calnex/P3/DataDownload/; CalNex Science Team, 2010) and SENEX (https://esrl.noaa.gov/csd/groups/csd7/measurements/ 2013senex/P3/DataDownload/; SENEX Science Team, 2013) data are available via the NOAA ESRL data archive. GoAmazon data were obtained from the Atmospheric Radiation Measurement (ARM) user facility (https://doi.org/10.5439/1346559; Martin et al., 2015), a U.S. Department of Energy (DOE) Office of Science user facility managed by the Office of Biological and Environmental Research.

Supplement. The supplement related to this article is available online at: https://doi.org/10.5194/acp-20-2637-2020-supplement.

Author contributions. CLH designed the study. SJP modified the code, performed the simulations and led the analysis. JRP, SCF and EAM contributed to the GEOS-Chem organic aerosol simulation. JLJ, PCJ, BAN, AMM, HC, JES, RB, JHD and KV provided organic aerosol measurements used in the analysis. SJP and CLH wrote the paper with input from the coauthors and the acknowledged individuals listed below.
Competing interests. The authors declare that they have no conflict of interest.

Disclaimer. This paper has not been reviewed by the EPA, and thus no endorsement should be inferred.

Acknowledgements. The authors would like to acknowledge Katherine R. Travis, Jesse H. Kroll, Jeffrey L. Collett Jr. and Taehyoung Lee for useful discussions and inputs. We also acknowledge the following investigators, who provided measurements of $\mathrm{NO}_{x}, \mathrm{CO}$ and isoprene: Andrew J. Weinheimer, Armin Wisthaler, Bruce C. Daube, Carsten Warneke, Chelsea R. Thompson, David J. Knapp, Denise D. Montzka, Donald R. Blake, Eric A. Kort, Eric C. Apel, Frank M. Flocke, Glen Sachse, Glenn S. Diskin, Ilana B. Pollack, Jeffrey Peischl, John E. Shilling, John S. Holloway, Joost A. de Gouw, Lisa Kaser, Markus Müller, Martin Graus, Philipp Eichler, Rebecca S. Hornbrook, Roisin Commane, Sally E. Pusede, Stephen R. Springston, Steven C. Wofsy, Teresa L. Campos, Thomas B. Ryerson, Tomas Mikoviny. Roya Bahreini was supported by the Colorado Department of Public Health and Environment. The art for Fig. 1 was obtained and modified from public domain images.

Financial support. This work was supported by the National Science Foundation (AGS-1564495). John E. Shilling was supported by the U.S. Department of Energy Office of Biological and Environmental Research as part of the ARM and ASR programs. The Pacific Northwest National Laboratory is operated for DOE by Battelle Memorial Institute under contract DE-AC05-76RL01830. Jeffrey R. Pierce was supported by the U.S. NSF (AGS-1559607) and the NOAA 31 (NA17OAR430001). Aerosol measurements from the EUCAARI and OP3 campaigns was collected under NERC grants NE/D013690/1, NE/D004624/1 and NE/E01108X/1. The CU-Boulder group was supported by NASA (NNX15AH33, NNX15AT96G, and 80NSSC18K0630), EPA STAR (83587701-0), and DOE (DE-SC0016559). PTR-MS measurements during DC3 and KORUS-AQ were supported by the Austrian Federal Ministry for Transport, Innovation and Technology through the Austrian Space Applications Programme (ASAP) of the Austrian Research Promotion Agency (FFG).

Review statement. This paper was edited by Neil M. Donahue and reviewed by two anonymous referees.

\section{References}

Amos, H. M., Jacob, D. J., Holmes, C. D., Fisher, J. A., Wang, Q., Yantosca, R. M., Corbitt, E. S., Galarneau, E., Rutter, A. P., Gustin, M. S., Steffen, A., Schauer, J. J., Graydon, J. A., Louis, V. L. St., Talbot, R. W., Edgerton, E. S., Zhang, Y., and Sunderland, E. M.: Gas-particle partitioning of atmospheric $\mathrm{Hg}$ (II) and its effect on global mercury deposition, Atmos. Chem. Phys., 12, 591-603, https://doi.org/10.5194/acp-12-591-2012, 2012. 
ARCPAC Science Team: ARCPAC, available at: https: //esrl.noaa.gov/csd/groups/csd7/measurements/2008ARCPAC/ P3/DataDownload (last access: 17 July 2017), 2008.

Bahreini, R., Ervens, B., Middlebrook, A. M., Warneke, C., de Gouw, J. A., DeCarlo, P. F., Jimenez, J. L., Brock, C. A., Neuman, J. A., Ryerson, T. B., Stark, H., Atlas, E., Brioude, J., Fried, A., Holloway, J. S., Peischl, J., Richter, D., Walega, J., Weibring, P., Wollny, A. G., and Fehsenfeld, F. C.: Organic aerosol formation in urban and industrial plumes near Houston and Dallas, Texas, J. Geophys. Res., 114, D00F16, https://doi.org/10.1029/2008JD011493, 2009.

Bahreini, R., Ahmadov, R., McKeen, S. A., Vu, K. T., Dingle, J. H., Apel, E. C., Blake, D. R., Blake, N., Campos, T. L., Cantrell, C., Flocke, F., Fried, A., Gilman, J. B., Hills, A. J., Hornbrook, R. S., Huey, G., Kaser, L., Lerner, B. M., Mauldin, R. L., Meinardi, S., Montzka, D. D., Richter, D., Schroeder, J. R., Stell, M., Tanner, D., Walega, J., Weibring, P., and Weinheimer, A.: Sources and characteristics of summertime organic aerosol in the Colorado Front Range: perspective from measurements and WRF-Chem modeling, Atmos. Chem. Phys., 18, 8293-8312, https://doi.org/10.5194/acp-18-8293-2018, 2018.

Barth, M. C., Cantrell, C. A., Brune, W. H., Rutledge, S. A., Crawford, J. H., Huntrieser, H., Carey, L. D., MacGorman, D., Weisman, M., Pickering, K. E., Bruning, E., Anderson, B., Apel, E., Biggerstaff, M., Campos, T., Campuzano-Jost, P., Cohen, R., Crounse, J., Day, D. A., Diskin, G., Flocke, F., Fried, A., Garland, C., Heikes, B., Honomichl, S., Hornbrook, R., Huey, L. G., Jimenez, J. L., Lang, T., Lichtenstern, M., Mikoviny, T., Nault, B., O'Sullivan, D., Pan, L. L., Peischl, J., Pollack, I., Richter, D., Riemer, D., Ryerson, T., Schlager, H., St. Clair, J., Walega, J., Weibring, P., Weinheimer, A., Wennberg, P., Wisthaler, A., Wooldridge, P. J., and Ziegler, C.: The Deep Convective Clouds and Chemistry (DC3) Field Campaign, B. Am. Meteorol. Soc., 96, 1281-1309, https://doi.org/10.1175/BAMSD-13-00290.1, 2014.

Brégonzio-Rozier, L., Giorio, C., Siekmann, F., Pangui, E., Morales, S. B., Temime-Roussel, B., Gratien, A., Michoud, V., Cazaunau, M., DeWitt, H. L., Tapparo, A., Monod, A., and Doussin, J.-F.: Secondary organic aerosol formation from isoprene photooxidation during cloud condensationevaporation cycles, Atmos. Chem. Phys., 16, 1747-1760, https://doi.org/10.5194/acp-16-1747-2016, 2016.

Brock, C. A., Cozic, J., Bahreini, R., Froyd, K. D., Middlebrook, A. M., McComiskey, A., Brioude, J., Cooper, O. R., Stohl, A., Aikin, K. C., de Gouw, J. A., Fahey, D. W., Ferrare, R. A., Gao, R.-S., Gore, W., Holloway, J. S., Hübler, G., Jefferson, A., Lack, D. A., Lance, S., Moore, R. H., Murphy, D. M., Nenes, A., Novelli, P. C., Nowak, J. B., Ogren, J. A., Peischl, J., Pierce, R. B., Pilewskie, P., Quinn, P. K., Ryerson, T. B., Schmidt, K. S., Schwarz, J. P., Sodemann, H., Spackman, J. R., Stark, H., Thomson, D. S., Thornberry, T., Veres, P., Watts, L. A., Warneke, C., and Wollny, A. G.: Characteristics, sources, and transport of aerosols measured in spring 2008 during the aerosol, radiation, and cloud processes affecting Arctic Climate (ARCPAC) Project, Atmos. Chem. Phys., 11, 2423 2453, https://doi.org/10.5194/acp-11-2423-2011, 2011.

Budisulistiorini, S. H., Nenes, A., Carlton, A. G., Surratt, J. D., McNeill, V. F., and Pye, H. O. T.: Simulating Aqueous-Phase Isoprene-Epoxydiol (IEPOX) Secondary Or- ganic Aerosol Production During the 2013 Southern Oxidant and Aerosol Study (SOAS), Environ. Sci. Technol., 51, 5026-5034, https://doi.org/10.1021/acs.est.6b05750, 2017.

CalNex Science Team: CalNex, available at: https://esrl.noaa.gov/ csd/groups/csd7/measurements/2010calnex/P3/DataDownload (last access: 17 July 2017), 2010.

Canagaratna, M. R., Jayne, J. T., Jimenez, J. L., Allan, J. D., Alfarra, M. R., Zhang, Q., Onasch, T. B., Drewnick, F., Coe, H., Middlebrook, A., Delia, A., Williams, L. R., Trimborn, A. M., Northway, M. J., DeCarlo, P. F., Kolb, C. E., Davidovits, P., and Worsnop, D. R.: Chemical and microphysical characterization of ambient aerosols with the aerodyne aerosol mass spectrometer, Mass Spectrom. Rev., 26, 185-222, https://doi.org/10.1002/mas.20115, 2007.

Chan Miller, C., Jacob, D. J., Marais, E. A., Yu, K., Travis, K. R., Kim, P. S., Fisher, J. A., Zhu, L., Wolfe, G. M., Hanisco, T. F., Keutsch, F. N., Kaiser, J., Min, K.-E., Brown, S. S., Washenfelder, R. A., González Abad, G., and Chance, K.: Glyoxal yield from isoprene oxidation and relation to formaldehyde: chemical mechanism, constraints from SENEX aircraft observations, and interpretation of OMI satellite data, Atmos. Chem. Phys., 17, 8725-8738, https://doi.org/10.5194/acp-17-8725-2017, 2017.

Chen, G.: KorUS-AQ Airborne Mission [Data set], https://doi.org/10.5067/SUBORBITAL/KORUSAQ/DATA01, 2018.

Chen, G.: All Data from the Arctic Research of the Composition of the Troposphere from Aircraft and Satellites (ARCTAS) NASA Airborne Mission [Data set], NASA Langley Atmospheric Science Data Center DAAC, https://doi.org/10.5067/ SUBORBITAL/ARCTAS2008/DATA001, 2020.

Chin, M., Ginoux, P., Kinne, S., Torres, O., Holben, B. N., Duncan, B. N., Martin, R. V., Logan, J. A., Higurashi, A., and Nakajima, T.: Tropospheric Aerosol Optical Thickness from the GOCART Model and Comparisons with Satellite and Sun Photometer Measurements, J. Atmos. Sci., 59, 461-483, https://doi.org/10.1175/15200469(2002)059<0461:TAOTFT>2.0.CO;2, 2002.

Chung, S. H. and Seinfeld, J. H.: Global distribution and climate forcing of carbonaceous aerosols, J. Geophys. Res., 107, 4407, https://doi.org/10.1029/2001JD001397, 2002.

Cohen, A. J., Brauer, M., Burnett, R., Anderson, H. R., Frostad, J., Estep, K., Balakrishnan, K., Brunekreef, B., Dandona, L., Dandona, R., Feigin, V., Freedman, G., Hubbell, B., Jobling, A., Kan, H., Knibbs, L., Liu, Y., Martin, R., Morawska, L., Pope, C. A., Shin, H., Straif, K., Shaddick, G., Thomas, M., Dingenen, R. van, Donkelaar, A. van, Vos, T., Murray, C. J. L., and Forouzanfar, M. H.: Estimates and 25-year trends of the global burden of disease attributable to ambient air pollution: an analysis of data from the Global Burden of Diseases Study 2015, Lancet, 389, 1907-1918, https://doi.org/10.1016/S0140-6736(17)30505-6, 2017.

Cooke, W. F., Liousse, C., Cachier, H., and Feichter, J.: Construction of a $1^{\circ} \times 1^{\circ}$ fossil fuel emission data set for carbonaceous aerosol and implementation and radiative impact in the ECHAM4 model, J. Geophys. Res.-Atmos., 104, 22137-22162, https://doi.org/10.1029/1999JD900187, 1999.

Crounse, J. D., Nielsen, L. B., Jørgensen, S., Kjaergaard, H. G., and Wennberg, P. O.: Autoxidation of Organic Compounds in the Atmosphere, J. Phys. Chem. Lett., 4, 3513-3520, https://doi.org/10.1021/jz4019207, 2013. 
Cubison, M. J., Ortega, A. M., Hayes, P. L., Farmer, D. K., Day, D., Lechner, M. J., Brune, W. H., Apel, E., Diskin, G. S., Fisher, J. A., Fuelberg, H. E., Hecobian, A., Knapp, D. J., Mikoviny, T., Riemer, D., Sachse, G. W., Sessions, W., Weber, R. J., Weinheimer, A. J., Wisthaler, A., and Jimenez, J. L.: Effects of aging on organic aerosol from open biomass burning smoke in aircraft and laboratory studies, Atmos. Chem. Phys., 11, 12049-12064, https://doi.org/10.5194/acp-11-12049-2011, 2011.

D’Ambro, E. L., Møller, K. H., Lopez-Hilfiker, F. D., Schobesberger, S., Liu, J., Shilling, J. E., Lee, B. H., Kjaergaard, H. G., and Thornton, J. A.: Isomerization of Second-Generation Isoprene Peroxy Radicals: Epoxide Formation and Implications for Secondary Organic Aerosol Yields, Environ. Sci. Technol., 51, 4978-4987, https://doi.org/10.1021/acs.est.7b00460, 2017.

DC3 Science Team: DC3 Field Campaign Data from DC-8 aircraft [Data set], NASA Langley Atmospheric Science Data Center DAAC, https://doi.org/10.5067/AIRCRAFT/DC3/DC8/AEROSOLTRACEGAS, 2012.

Dingle, J. H., Vu, K., Bahreini, R., Apel, E. C., Campos, T. L., Flocke, F., Fried, A., Herndon, S., Hills, A. J., Hornbrook, R. S., Huey, G., Kaser, L., Montzka, D. D., Nowak, J. B., Reeves, M., Richter, D., Roscioli, J. R., Shertz, S., Stell, M., Tanner, D., Tyndall, G., Walega, J., Weibring, P., and Weinheimer, A.: Aerosol optical extinction during the Front Range Air Pollution and Photochemistry Éxperiment (FRAPPÉ) 2014 summertime field campaign, Colorado, USA, Atmos. Chem. Phys., 16, 11207-11217, https://doi.org/10.5194/acp-16-11207-2016, 2016.

Donahue, N. M., Robinson, A. L., Stanier, C. O., and Pandis, S. N.: Coupled Partitioning, Dilution, and Chemical Aging of Semivolatile Organics, Environ. Sci. Technol., 40, 2635-2643, https://doi.org/10.1021/es052297c, 2006.

EUCAARI Science Team: EUCAARI, available at: http://data.ceda. ac.uk/badc/appraise/data/adient (last access: 3 August 2011), 2008.

Fairlie, D. T., Jacob, D. J., and Park, R. J.: The impact of transpacific transport of mineral dust in the United States, Atmos. Environ., 41, 1251-1266, https://doi.org/10.1016/j.atmosenv.2006.09.048, 2007.

Fisher, J. A., Jacob, D. J., Wang, Q., Bahreini, R., Carouge, C. C., Cubison, M. J., Dibb, J. E., Diehl, T., Jimenez, J. L., Leibensperger, E. M., Lu, Z., Meinders, M. B. J., Pye, H. O. T., Quinn, P. K., Sharma, S., Streets, D. G., van Donkelaar, A., and Yantosca, R. M.: Sources, distribution, and acidity of sulfate-ammonium aerosol in the Arctic in winter-spring, Atmos. Environ., 45, 7301-7318, https://doi.org/10.1016/j.atmosenv.2011.08.030, 2011.

Fisher, J. A., Jacob, D. J., Travis, K. R., Kim, P. S., Marais, E. A., Chan Miller, C., Yu, K., Zhu, L., Yantosca, R. M., Sulprizio, M. P., Mao, J., Wennberg, P. O., Crounse, J. D., Teng, A. P., Nguyen, T. B., St. Clair, J. M., Cohen, R. C., Romer, P., Nault, B. A., Wooldridge, P. J., Jimenez, J. L., CampuzanoJost, P., Day, D. A., Hu, W., Shepson, P. B., Xiong, F., Blake, D. R., Goldstein, A. H., Misztal, P. K., Hanisco, T. F., Wolfe, G. M., Ryerson, T. B., Wisthaler, A., and Mikoviny, T.: Organic nitrate chemistry and its implications for nitrogen budgets in an isoprene- and monoterpene-rich atmosphere: constraints from aircraft $\left(\mathrm{SEAC}^{4} \mathrm{RS}\right)$ and ground-based (SOAS) observa- tions in the Southeast US, Atmos. Chem. Phys., 16, 5969-5991, https://doi.org/10.5194/acp-16-5969-2016, 2016.

Fountoukis, C. and Nenes, A.: ISORROPIA II: a computationally efficient thermodynamic equilibrium model for $\mathrm{K}^{+}-$ $\mathrm{Ca}^{2+}-\mathrm{Mg}^{2+}-\mathrm{NH}_{4}^{+}-\mathrm{Na}^{+}-\mathrm{SO}_{4}^{2-}-\mathrm{NO}_{3}^{-}-\mathrm{Cl}^{-}-\mathrm{H}_{2} \mathrm{O}$ aerosols, Atmos. Chem. Phys., 7, 4639-4659, https://doi.org/10.5194/acp-74639-2007, 2007.

FRAPPE Science Team: FRAPPE, available at: https://www-air. larc.nasa.gov/cgi-bin/ArcView/discover-aq.co-2014?C130=1 (last access: 18 July 2017), 2014.

Gantt, B., Johnson, M. S., Crippa, M., Prévôt, A. S. H., and Meskhidze, N.: Implementing marine organic aerosols into the GEOS-Chem model, Geosci. Model Dev., 8, 619-629, https://doi.org/10.5194/gmd-8-619-2015, 2015.

Giorio, C., Monod, A., Brégonzio-Rozier, L., DeWitt, H. L., Cazaunau, M., Temime-Roussel, B., Gratien, A., Michoud, V., Pangui, E., Ravier, S., Zielinski, A. T., Tapparo, A., Vermeylen, R., Claeys, M., Voisin, D., Kalberer, M., and Doussin, J.-F.: Cloud Processing of Secondary Organic Aerosol from Isoprene and Methacrolein Photooxidation, J. Phys. Chem. A, 121, 76417654, https://doi.org/10.1021/acs.jpca.7b05933, 2017.

GoAmazon Science Team: GoAmazon data, available at: https: //www.arm.gov/research/campaigns/amf2014goamazon (last access: 17 July 2017), 2014.

Goldberg, D. L., Saide, P. E., Lamsal, L. N., de Foy, B., Lu, Z., Woo, J.-H., Kim, Y., Kim, J., Gao, M., Carmichael, G., and Streets, D. G.: A top-down assessment using $\mathrm{OMI} \mathrm{NO}_{2}$ suggests an underestimate in the $\mathrm{NO}_{x}$ emissions inventory in Seoul, South Korea, during KORUS-AQ, Atmos. Chem. Phys., 19, 1801-1818, https://doi.org/10.5194/acp-19-1801-2019, 2019.

Grieshop, A. P., Logue, J. M., Donahue, N. M., and Robinson, A. L.: Laboratory investigation of photochemical oxidation of organic aerosol from wood fires 1: measurement and simulation of organic aerosol evolution, Atmos. Chem. Phys., 9, 1263-1277, https://doi.org/10.5194/acp-9-1263-2009, 2009.

Guenther, A. B., Jiang, X., Heald, C. L., Sakulyanontvittaya, T., Duhl, T., Emmons, L. K., and Wang, X.: The Model of Emissions of Gases and Aerosols from Nature version 2.1 (MEGAN2.1): an extended and updated framework for modeling biogenic emissions, Geosci. Model Dev., 5, 1471-1492, https://doi.org/10.5194/gmd-5-1471-2012, 2012.

Hayes, P. L., Carlton, A. G., Baker, K. R., Ahmadov, R., Washenfelder, R. A., Alvarez, S., Rappenglück, B., Gilman, J. B., Kuster, W. C., de Gouw, J. A., Zotter, P., Prévôt, A. S. H., Szidat, S., Kleindienst, T. E., Offenberg, J. H., Ma, P. K., and Jimenez, J. L.: Modeling the formation and aging of secondary organic aerosols in Los Angeles during CalNex 2010, Atmos. Chem. Phys., 15, 5773-5801, https://doi.org/10.5194/acp-15-5773-2015, 2015.

Heald, C. L., Jacob, D. J., Park, R. J., Russell, L. M., Huebert, B. J., Seinfeld, J. H., Liao, H., and Weber, R. J.: A large organic aerosol source in the free troposphere missing from current models, Geophys. Res. Lett., 32, L18809, https://doi.org/10.1029/2005GL023831, 2005.

Heald, C. L., Coe, H., Jimenez, J. L., Weber, R. J., Bahreini, R., Middlebrook, A. M., Russell, L. M., Jolleys, M., Fu, T.-M., Allan, J. D., Bower, K. N., Capes, G., Crosier, J., Morgan, W. T., Robinson, N. H., Williams, P. I., Cubison, M. J., DeCarlo, P. F., and Dunlea, E. J.: Exploring the vertical profile of atmospheric organic aerosol: comparing 17 aircraft field campaigns 
with a global model, Atmos. Chem. Phys., 11, 12673-12696, https://doi.org/10.5194/acp-11-12673-2011, 2011.

Hewitt, C. N., Lee, J. D., MacKenzie, A. R., Barkley, M. P., Carslaw, N., Carver, G. D., Chappell, N. A., Coe, H., Collier, C., Commane, R., Davies, F., Davison, B., DiCarlo, P., Di Marco, C. F., Dorsey, J. R., Edwards, P. M., Evans, M. J., Fowler, D., Furneaux, K. L., Gallagher, M., Guenther, A., Heard, D. E., Helfter, C., Hopkins, J., Ingham, T., Irwin, M., Jones, C., Karunaharan, A., Langford, B., Lewis, A. C., Lim, S. F., MacDonald, S. M., Mahajan, A. S., Malpass, S., McFiggans, G., Mills, G., Misztal, P., Moller, S., Monks, P. S., Nemitz, E., Nicolas-Perea, V., Oetjen, H., Oram, D. E., Palmer, P. I., Phillips, G. J., Pike, R., Plane, J. M. C., Pugh, T., Pyle, J. A., Reeves, C. E., Robinson, N. H., Stewart, D., Stone, D., Whalley, L. K., and Yang, X.: Corrigendum to "Overview: oxidant and particle photochemical processes above a south-east Asian tropical rainforest (the OP3 project): introduction, rationale, location characteristics and tools" published in Atmos. Chem. Phys., 10, 169-199, 2010, Atmos. Chem. Phys., 10, 563-563, https://doi.org/10.5194/acp-10-563-2010, 2010.

Hodzic, A., Kasibhatla, P. S., Jo, D. S., Cappa, C. D., Jimenez, J. L., Madronich, S., and Park, R. J.: Rethinking the global secondary organic aerosol (SOA) budget: stronger production, faster removal, shorter lifetime, Atmos. Chem. Phys., 16, 7917-7941, https://doi.org/10.5194/acp-16-7917-2016, 2016.

Hoesly, R. M., Smith, S. J., Feng, L., Klimont, Z., JanssensMaenhout, G., Pitkanen, T., Seibert, J. J., Vu, L., Andres, R. J., Bolt, R. M., Bond, T. C., Dawidowski, L., Kholod, N., Kurokawa, J.-I., Li, M., Liu, L., Lu, Z., Moura, M. C. P., O'Rourke, P. R., and Zhang, Q.: Historical (1750-2014) anthropogenic emissions of reactive gases and aerosols from the Community Emissions Data System (CEDS), Geosci. Model Dev., 11, 369-408, https://doi.org/10.5194/gmd-11-369-2018, 2018.

Holmes, C. D., Prather, M. J., and Vinken, G. C. M.: The climate impact of ship $\mathrm{NO}_{x}$ emissions: an improved estimate accounting for plume chemistry, Atmos. Chem. Phys., 14, 6801-6812, https://doi.org/10.5194/acp-14-6801-2014, 2014.

Hudman, R. C., Moore, N. E., Mebust, A. K., Martin, R. V., Russell, A. R., Valin, L. C., and Cohen, R. C.: Steps towards a mechanistic model of global soil nitric oxide emissions: implementation and space based-constraints, Atmos. Chem. Phys., 12, 7779-7795, https://doi.org/10.5194/acp-12-7779-2012, 2012.

Huffman, J. A., Docherty, K. S., Mohr, C., Cubison, M. J., U1brich, I. M., Ziemann, P. J., Onasch, T. B., and Jimenez, J. L.: Chemically-Resolved Volatility Measurements of Organic Aerosol from Different Sources, Environ. Sci. Technol., 43, 5351-5357, https://doi.org/10.1021/es803539d, 2009.

International GEOS-Chem User Community: geoschem/geoschem: GEOS-Chem 12.1.1 (Version 12.1.1), Zenodo, https://doi.org/10.5281/zenodo.2249246, 2018.

IPCC: Climate Change 2013: The Physical Science Basis. Contribution of Working Group I to the Fifth Assessment Report of the Intergovernmental Panel on Climate Change, edited by: Stocker, T. F., Qin, D., Plattner, G.-K., Tignor, M., Allen, S. K., Boschung, J., Nauels, A., Xia, Y., Bex, V., and Midgley, P. M.,, Cambridge University Press, Cambridge, United Kingdom and New York, NY, USA, available at: https://www.ipcc.ch/site/assets/uploads/ 2018/02/WG1AR5_all_final.pdf (last access: 11 February 2019), 2013.
Jacob, D. J., Liu, H., Mari, C., and Yantosca, R. M.: Harvard wet deposition scheme for GMI, 6, available at: http://acmg.seas.harvard.edu/geos/wiki_docs/deposition/ wetdep.jacob_etal_2000.pdf (last access: 5 December 2019), 2000.

Jacob, D. J., Crawford, J. H., Maring, H., Clarke, A. D., Dibb, J. E., Emmons, L. K., Ferrare, R. A., Hostetler, C. A., Russell, P. B., Singh, H. B., Thompson, A. M., Shaw, G. E., McCauley, E., Pederson, J. R., and Fisher, J. A.: The Arctic Research of the Composition of the Troposphere from Aircraft and Satellites (ARCTAS) mission: design, execution, and first results, Atmos. Chem. Phys., 10, 5191-5212, https://doi.org/10.5194/acp10-5191-2010, 2010.

Jaeglé, L., Quinn, P. K., Bates, T. S., Alexander, B., and Lin, J.-T.: Global distribution of sea salt aerosols: new constraints from in situ and remote sensing observations, Atmos. Chem. Phys., 11, 3137-3157, https://doi.org/10.5194/acp-11-3137-2011, 2011.

Jayne, J. T., Leard, D. C., Zhang, X., Davidovits, P., Smith, K. A., Kolb, C. E., and Worsnop, D. R.: Development of an Aerosol Mass Spectrometer for Size and Composition Analysis of Submicron Particles, Aerosol Sci. Technol., 33, 49-70, https://doi.org/10.1080/027868200410840, 2000.

Jimenez, J. L., Canagaratna, M. R., Donahue, N. M., Prevot, A. S. H., Zhang, Q., Kroll, J. H., DeCarlo, P. F., Allan, J. D., Coe, H., Ng, N. L., Aiken, A. C., Docherty, K. S., Ulbrich, I. M., Grieshop, A. P., Robinson, A. L., Duplissy, J., Smith, J. D., Wilson, K. R., Lanz, V. A., Hueglin, C., Sun, Y. L., Tian, J., Laaksonen, A., Raatikainen, T., Rautiainen, J., Vaattovaara, P., Ehn, M., Kulmala, M., Tomlinson, J. M., Collins, D. R., Cubison, M. J., E, Dunlea, J., Huffman, J. A., Onasch, T. B., Alfarra, M. R., Williams, P. I., Bower, K., Kondo, Y., Schneider, J., Drewnick, F., Borrmann, S., Weimer, S., Demerjian, K., Salcedo, D., Cottrell, L., Griffin, R., Takami, A., Miyoshi, T., Hatakeyama, S., Shimono, A., Sun, J. Y., Zhang, Y. M., Dzepina, K., Kimmel, J. R., Sueper, D., Jayne, J. T., Herndon, S. C., Trimborn, A. M., Williams, L. R., Wood, E. C., Middlebrook, A. M., Kolb, C. E., Baltensperger, U., and Worsnop, D. R.: Evolution of Organic Aerosols in the Atmosphere, Science, 326, 1525-1529, https://doi.org/10.1126/science.1180353, 2009.

Jo, D. S., Hodzic, A., Emmons, L. K., Marais, E. A., Peng, Z., Nault, B. A., Hu, W., Campuzano-Jost, P., and Jimenez, J. L.: A simplified parameterization of isoprene-epoxydiol-derived secondary organic aerosol (IEPOX-SOA) for global chemistry and climate models: a case study with GEOS-Chem v11-02-rc, Geosci. Model Dev., 12, 2983-3000, https://doi.org/10.5194/gmd-122983-2019, 2019.

Jolleys, M. D., Coe, H., McFiggans, G., McMeeking, G. R., Lee, T., Kreidenweis, S. M., Collett, J. L., and Sullivan, A. P.: Organic aerosol emission ratios from the laboratory combustion of biomass fuels: BBOA emission ratios in chamber studies, J. Geophys. Res.-Atmos., 119, 12850-12871, https://doi.org/10.1002/2014JD021589, 2014.

Kanakidou, M., Seinfeld, J. H., Pandis, S. N., Barnes, I., Dentener, F. J., Facchini, M. C., Van Dingenen, R., Ervens, B., Nenes, A., Nielsen, C. J., Swietlicki, E., Putaud, J. P., Balkanski, Y., Fuzzi, S., Horth, J., Moortgat, G. K., Winterhalter, R., Myhre, C. E. L., Tsigaridis, K., Vignati, E., Stephanou, E. G., and Wilson, J.: Organic aerosol and global climate modelling: a review, Atmos. 
Chem. Phys., 5, 1053-1123, https://doi.org/10.5194/acp-5-10532005, 2005.

Keller, C. A., Long, M. S., Yantosca, R. M., Da Silva, A. M., Pawson, S., and Jacob, D. J.: HEMCO v1.0: a versatile, ESMF-compliant component for calculating emissions in atmospheric models, Geosci. Model Dev., 7, 1409-1417, https://doi.org/10.5194/gmd-7-1409-2014, 2014.

Kiendler-Scharr, A., Mensah, A. A., Friese, E., Topping, D., Nemitz, E., Prevot, A. S. H., Äijälä, M., Allan, J., Canonaco, F., Canagaratna, M., Carbone, S., Crippa, M., Osto, M. D., Day, D. A., Carlo, P. D., Marco, C. F. D., Elbern, H., Eriksson, A., Freney, E., Hao, L., Herrmann, H., Hildebrandt, L., Hillamo, R., Jimenez, J. L., Laaksonen, A., McFiggans, G., Mohr, C., O'Dowd, C., Otjes, R., Ovadnevaite, J., Pandis, S. N., Poulain, L., Schlag, P., Sellegri, K., Swietlicki, E., Tiitta, P., Vermeulen, A., Wahner, A., Worsnop, D., and Wu, H.-C.: Ubiquity of organic nitrates from nighttime chemistry in the European submicron aerosol, Geophys. Res. Lett., 43, 7735-7744, https://doi.org/10.1002/2016GL069239, 2016.

Kim, P. S., Jacob, D. J., Fisher, J. A., Travis, K., Yu, K., Zhu, L., Yantosca, R. M., Sulprizio, M. P., Jimenez, J. L., CampuzanoJost, P., Froyd, K. D., Liao, J., Hair, J. W., Fenn, M. A., Butler, C. F., Wagner, N. L., Gordon, T. D., Welti, A., Wennberg, P. O., Crounse, J. D., St. Clair, J. M., Teng, A. P., Millet, D. B., Schwarz, J. P., Markovic, M. Z., and Perring, A. E.: Sources, seasonality, and trends of southeast US aerosol: an integrated analysis of surface, aircraft, and satellite observations with the GEOS-Chem chemical transport model, Atmos. Chem. Phys., 15, 10411-10433, https://doi.org/10.5194/acp-15-104112015, 2015.

Kroll, J. H., Ng, N. L., Murphy, S. M., Flagan, R. C., and Seinfeld, J. H.: Secondary Organic Aerosol Formation from Isoprene Photooxidation, Environ. Sci. Technol., 40, 1869-1877, https://doi.org/10.1021/es0524301, 2006.

Kuhns, H., Knipping, E. M., and Vukovich, J. M.: Development of a United States-Mexico Emissions Inventory for the Big Bend Regional Aerosol and Visibility Observational (BRAVO) Study, J. Air Waste Manage., 55, 677-692, https://doi.org/10.1080/10473289.2005.10464648, 2005.

Li, J., Cleveland, M., Ziemba, L. D., Griffin, R. J., Barsanti, K. C., Pankow, J. F., and Ying, Q.: Modeling regional secondary organic aerosol using the Master Chemical Mechanism, Atmos. Environ., 102, 52-61, https://doi.org/10.1016/j.atmosenv.2014.11.054, 2015.

Li, M., Zhang, Q., Kurokawa, J.-I., Woo, J.-H., He, K., Lu, Z., Ohara, T., Song, Y., Streets, D. G., Carmichael, G. R., Cheng, Y., Hong, C., Huo, H., Jiang, X., Kang, S., Liu, F., Su, H., and Zheng, B.: MIX: a mosaic Asian anthropogenic emission inventory under the international collaboration framework of the MICS-Asia and HTAP, Atmos. Chem. Phys., 17, 935-963, https://doi.org/10.5194/acp-17-935-2017, 2017.

Lin, G., Penner, J. E., Sillman, S., Taraborrelli, D., and Lelieveld, J.: Global modeling of SOA formation from dicarbonyls, epoxides, organic nitrates and peroxides, Atmos. Chem. Phys., 12, 47434774, https://doi.org/10.5194/acp-12-4743-2012, 2012.

Lipsky, E. M. and Robinson, A. L.: Effects of Dilution on Fine Particle Mass and Partitioning of Semivolatile Organics in Diesel Exhaust and Wood Smoke, Environ. Sci. Technol., 40, 155-162, https://doi.org/10.1021/es050319p, 2006.
Liu, H., Jacob, D. J., Bey, I., and Yantosca, R. M.: Constraints from ${ }^{210} \mathrm{~Pb}$ and ${ }^{7} \mathrm{Be}$ on wet deposition and transport in a global threedimensional chemical tracer model driven by assimilated meteorological fields, J. Geophys. Res.-Atmos., 106, 12109-12128, https://doi.org/10.1029/2000JD900839, 2001.

Mao, J., Paulot, F., Jacob, D. J., Cohen, R. C., Crounse, J. D., Wennberg, P. O., Keller, C. A., Hudman, R. C., Barkley, M. P., and Horowitz, L. W.: Ozone and organic nitrates over the eastern United States: Sensitivity to isoprene chemistry: OZONE AND ORGANIC NITRATES OVER EAST U.S., J. Geophys. Res.Atmos., 118, 11256-11268, https://doi.org/10.1002/jgrd.50817, 2013.

Marais, E. A. and Wiedinmyer, C.: Air Quality Impact of Diffuse and Inefficient Combustion Emissions in Africa (DICE-Africa), Environ. Sci. Technol., 50, 10739-10745, https://doi.org/10.1021/acs.est.6b02602, 2016.

Marais, E. A., Jacob, D. J., Jimenez, J. L., Campuzano-Jost, P., Day, D. A., Hu, W., Krechmer, J., Zhu, L., Kim, P. S., Miller, C. C., Fisher, J. A., Travis, K., Yu, K., Hanisco, T. F., Wolfe, G. M., Arkinson, H. L., Pye, H. O. T., Froyd, K. D., Liao, J., and McNeill, V. F.: Aqueous-phase mechanism for secondary organic aerosol formation from isoprene: application to the southeast United States and co-benefit of $\mathrm{SO}_{2}$ emission controls, Atmos. Chem. Phys., 16, 1603-1618, https://doi.org/10.5194/acp16-1603-2016, 2016.

Marais, E. A., Jacob, D. J., Turner, J. R., and Mickley, L. J.: Evidence of 1991-2013 decrease of biogenic secondary organic aerosol in response to $\mathrm{SO}_{2}$ emission controls, Environ. Res. Lett., 12, 054018, https://doi.org/10.1088/1748-9326/aa69c8, 2017.

Martin, R. V., Jacob, D. J., Yantosca, R. M., Chin, M., and Ginoux, P.: Global and regional decreases in tropospheric oxidants from photochemical effects of aerosols: Photochemical Effects Of Aerosols, J. Geophys. Res.-Atmos., 108, 4097, https://doi.org/10.1029/2002JD002622, 2003.

Martin, S., Mei, F., Alexander, L., Artaxo, P., Barbosa, H., Bartholomew, M. J., Biscaro, T., Buseck, P., Chand, D., Comstock, J., Dubey, M., Godstein, A., Guenther, A., Hubbe, J., Jardine, K., Jimenez, J.-L., Kim, S., Kuang, C., Laskin, A., Long, C., Paralovo, S., Petaja, T., Powers, H., Schumacher, C., Sedlacek, A., Senum, G., Smith, J., Shilling, J., Springston, S., Thayer, M., Tomlinson, J., Wang, J., and Xie, S.: Campaign datasets for Observations and Modeling of the Green Ocean Amazon (GOAMAZON) [Data set]. Atmospheric Radiation Measurement (ARM) Archive, Oak Ridge National Laboratory (ORNL), Oak Ridge, TN, USA, ARM Data Center, Oak Ridge National Laboratory (ORNL), Oak Ridge, TN, USA, https://doi.org/10.5439/1346559, 2015.

Martin, S. T., Artaxo, P., Machado, L. A. T., Manzi, A. O., Souza, R. A. F., Schumacher, C., Wang, J., Andreae, M. O., Barbosa, H. M. J., Fan, J., Fisch, G., Goldstein, A. H., Guenther, A., Jimenez, J. L., Pöschl, U., Silva Dias, M. A., Smith, J. N., and Wendisch, M.: Introduction: Observations and Modeling of the Green Ocean Amazon (GoAmazon2014/5), Atmos. Chem. Phys., 16, 47854797, https://doi.org/10.5194/acp-16-4785-2016, 2016.

McFiggans, G., Mentel, T. F., Wildt, J., Pullinen, I., Kang, S., Kleist, E., Schmitt, S., Springer, M., Tillmann, R., Wu, C., Zhao, D., Hallquist, M., Faxon, C., Le Breton, M., Hallquist, A. M., Simpson, D., Bergström, R., Jenkin, M. E., Ehn, M., Thornton, J. A., Alfarra, M. R., Bannan, T. J., Percival, C. J., Priestley, M., Top- 
ping, D., and Kiendler-Scharr, A.: Secondary organic aerosol reduced by mixture of atmospheric vapours, Nature, 565, 587-593, https://doi.org/10.1038/s41586-018-0871-y, 2019.

Morgan, W. T., Allan, J. D., Bower, K. N., Highwood, E. J., Liu, D., McMeeking, G. R., Northway, M. J., Williams, P. I., Krejci, R., and Coe, H.: Airborne measurements of the spatial distribution of aerosol chemical composition across Europe and evolution of the organic fraction, Atmos. Chem. Phys., 10, 4065-4083, https://doi.org/10.5194/acp-10-4065-2010, 2010.

Murphy, B. N., Donahue, N. M., Robinson, A. L., and Pandis, S. N.: A naming convention for atmospheric organic aerosol, Atmos. Chem. Phys., 14, 5825-5839, https://doi.org/10.5194/acp14-5825-2014, 2014.

Murray, L. T., Jacob, D. J., Logan, J. A., Hudman, R. C., and Koshak, W. J.: Optimized regional and interannual variability of lightning in a global chemical transport model constrained by LIS/OTD satellite data: IAV of lightning constrained by LIS/OTD, J. Geophys. Res.-Atmos., 117, D20307, https://doi.org/10.1029/2012JD017934, 2012.

Nault, B. A., Campuzano-Jost, P., Day, D. A., Schroder, J. C., Anderson, B., Beyersdorf, A. J., Blake, D. R., Brune, W. H., Choi, Y., Corr, C. A., de Gouw, J. A., Dibb, J., DiGangi, J. P., Diskin, G. S., Fried, A., Huey, L. G., Kim, M. J., Knote, C. J., Lamb, K. D., Lee, T., Park, T., Pusede, S. E., Scheuer, E., Thornhill, K. L., Woo, J.-H., and Jimenez, J. L.: Secondary organic aerosol production from local emissions dominates the organic aerosol budget over Seoul, South Korea, during KORUS-AQ, Atmos. Chem. Phys., 18, 17769-17800, https://doi.org/10.5194/acp-18-177692018, 2018.

Ng, N. L., Chhabra, P. S., Chan, A. W. H., Surratt, J. D., Kroll, J. H., Kwan, A. J., McCabe, D. C., Wennberg, P. O., Sorooshian, A., Murphy, S. M., Dalleska, N. F., Flagan, R. C., and Seinfeld, J. H.: Effect of $\mathrm{NO}_{x}$ level on secondary organic aerosol (SOA) formation from the photooxidation of terpenes, Atmos. Chem. Phys., 7, 5159-5174, https://doi.org/10.5194/acp-7-5159-2007, 2007.

Odum, J. R., Hoffmann, T., Bowman, F., Collins, D., Flagan, R. C., and Seinfeld, J. H.: Gas/Particle Partitioning and Secondary Organic Aerosol Yields, Environ. Sci. Technol., 30, 2580-2585, https://doi.org/10.1021/es950943+, 1996.

OP3 Science Team: OP3, available at: http://data.ceda.ac.uk/badc/ op3 (last access: 3 August 2011), 2008.

Ott, L. E., Pickering, K. E., Stenchikov, G. L., Allen, D. J., DeCaria, A. J., Ridley, B., Lin, R.-F., Lang, S., and Tao, W.-K.: Production of lightning $\mathrm{NO}_{x}$ and its vertical distribution calculated from three-dimensional cloud-scale chemical transport model simulations, J. Geophys. Res., 115, D04301, https://doi.org/10.1029/2009JD011880, 2010.

Pandis, S. N., Harley, R. A., Cass, G. R., and Seinfeld, J. H.: Secondary organic aerosol formation and transport, Atmos. Environ. A-Gen., 26, 2269-2282, https://doi.org/10.1016/09601686(92)90358-R, 1992.

Pankow, J. F.: An absorption model of the gas/aerosol partitioning involved in the formation of secondary organic aerosol, Atmos. Environ., 28, 189-193, https://doi.org/10.1016/13522310(94)90094-9, 1994.

Park, R. J.: Natural and transboundary pollution influences on sulfate-nitrate-ammonium aerosols in the United States: Implications for policy, J. Geophys. Res., 109, D15204, https://doi.org/10.1029/2003JD004473, 2004.
Park, R. J., Jacob, D. J., Martin, R. V., and Chin, M.: Sources of carbonaceous aerosols over the United States and implications for natural visibility, J. Geophys. Res., 108, 4355, https://doi.org/10.1029/2002JD003190, 2003.

Philip, S., Martin, R. V., and Keller, C. A.: Sensitivity of chemistrytransport model simulations to the duration of chemical and transport operators: a case study with GEOS-Chem v10-01, Geosci. Model Dev., 9, 1683-1695, https://doi.org/10.5194/gmd9-1683-2016, 2016.

Pope, C. A. and Dockery, D. W.: Health Effects of Fine Particulate Air Pollution: Lines that Connect, J. Air Waste Manage., 56, 709-742, https://doi.org/10.1080/10473289.2006.10464485, 2006.

Pye, H. O. T. and Seinfeld, J. H.: A global perspective on aerosol from low-volatility organic compounds, Atmos. Chem. Phys., 10, 4377-4401, https://doi.org/10.5194/acp-10-4377-2010, 2010.

Pye, H. O. T., Chan, A. W. H., Barkley, M. P., and Seinfeld, J. H.: Global modeling of organic aerosol: the importance of reactive nitrogen $\left(\mathrm{NO}_{x}\right.$ and $\left.\mathrm{NO}_{3}\right)$, Atmos. Chem. Phys., 10, 1126111276, https://doi.org/10.5194/acp-10-11261-2010, 2010.

Pye, H. O. T., D’Ambro, E. L., Lee, B. H., Schobesberger, S., Takeuchi, M., Zhao, Y., Lopez-Hilfiker, F., Liu, J., Shilling, J. E., Xing, J., Mathur, R., Middlebrook, A. M., Liao, J., Welti, A., Graus, M., Warneke, C., de Gouw, J. A., Holloway, J. S., Ryerson, T. B., Pollack, I. B., and Thornton, J. A.: Anthropogenic enhancements to production of highly oxygenated molecules from autoxidation, P. Natl. Acad. Sci. USA, 116, 6641-6646, https://doi.org/10.1073/pnas.1810774116, 2019.

Ramanathan, V., Crutzen, P. J., Kiehl, J. T., and Rosenfeld, D.: Aerosols, Climate, and the Hydrological Cycle, Science, 294, 2119-2124, https://doi.org/10.1126/science.1064034, 2001.

Rastigejev, Y., Park, R., Brenner, M. P., and Jacob, D. J.: Resolving intercontinental pollution plumes in global models of atmospheric transport, J. Geophys. Res., 115, D02302, https://doi.org/10.1029/2009JD012568, 2010.

Ridley, D. A., Heald, C. L., and Ford, B.: North African dust export and deposition: A satellite and model perspective, J. Geophys. Res.-Atmos., 117, D02202, https://doi.org/10.1029/2011JD016794, 2012.

Robinson, A. L., Donahue, N. M., Shrivastava, M. K., Weitkamp, E. A., Sage, A. M., Grieshop, A. P., Lane, T. E., Pierce, J. R., and Pandis, S. N.: Rethinking Organic Aerosols: Semivolatile Emissions and Photochemical Aging, Science, 315, 1259-1262, https://doi.org/10.1126/science.1133061, 2007.

Ryerson, T. B., Andrews, A. E., Angevine, W. M., Bates, T. S., Brock, C. A., Cairns, B., Cohen, R. C., Cooper, O. R., de Gouw, J. A., Fehsenfeld, F. C., Ferrare, R. A., Fischer, M. L., Flagan, R. C., Goldstein, A. H., Hair, J. W., Hardesty, R. M., Hostetler, C. A., Jimenez, J. L., Langford, A. O., McCauley, E., McKeen, S. A., Molina, L. T., Nenes, A., Oltmans, S. J., Parrish, D. D., Pederson, J. R., Pierce, R. B., Prather, K., Quinn, P. K., Seinfeld, J. H., Senff, C. J., Sorooshian, A., Stutz, J., Surratt, J. D., Trainer, M., Volkamer, R., Williams, E. J., and Wofsy, S. C.: The 2010 California Research at the Nexus of Air Quality and Climate Change (CalNex) field study, J. Geophys. Res.-Atmos., 118, 5830-5866, https://doi.org/10.1002/jgrd.50331, 2013.

Schauer, J. J., Kleeman, M. J., Cass, G. R., and Simoneit, B. R. T.: Measurement of Emissions from Air Pollution Sources. 3. C1-C29 Organic Compounds from Fireplace Com- 
bustion of Wood, Environ. Sci. Technol., 35, 1716-1728, https://doi.org/10.1021/es001331e, 2001.

Schroder, J. C., Campuzano-Jost, P., Day, D. A., Shah, V., Larson, K., Sommers, J. M., Sullivan, A. P., Campos, T., Reeves, J. M., Hills, A., Hornbrook, R. S., Blake, N. J., Scheuer, E., Guo, H., Fibiger, D. L., McDuffie, E. E., Hayes, P. L., Weber, R. J., Dibb, J. E., Apel, E. C., Jaeglé, L., Brown, S. S., Thornton, J. A., and Jimenez, J. L.: Sources and Secondary Production of Organic Aerosols in the Northeastern United States during WINTER, J. Geophys. Res.-Atmos., 123, 7771-7796, https://doi.org/10.1029/2018JD028475, 2018.

SEAC4RS Science Team: SEAC4RS Field Campaign Data [Data set], https://doi.org/10.5067/AIRCRAFT/SEAC4RS/ AEROSOL-TRACEGAS-CLOUD, 2014.

SENEX Science Team: SENEX, available at: https://esrl.noaa.gov/ csd/groups/csd7/measurements/2013senex/P3/DataDownload (last access: 17 July 2017), 2013.

Shah, V., Jaeglé, L., Jimenez, J. L., Schroder, J. C., CampuzanoJost, P., Campos, T. L., Reeves, J. M., Stell, M., Brown, S. S., Lee, B. H., Lopez-Hilfiker, F. D., and Thornton, J. A.: Widespread Pollution From Secondary Sources of Organic Aerosols During Winter in the Northeastern United States, Geophys. Res. Lett., 46, 2974-2983, https://doi.org/10.1029/2018GL081530, 2019.

Sherwen, T., Schmidt, J. A., Evans, M. J., Carpenter, L. J., Großmann, K., Eastham, S. D., Jacob, D. J., Dix, B., Koenig, T. K., Sinreich, R., Ortega, I., Volkamer, R., Saiz-Lopez, A., PradosRoman, C., Mahajan, A. S., and Ordóñez, C.: Global impacts of tropospheric halogens $(\mathrm{Cl}, \mathrm{Br}, \mathrm{I})$ on oxidants and composition in GEOS-Chem, Atmos. Chem. Phys., 16, 12239-12271, https://doi.org/10.5194/acp-16-12239-2016, 2016.

Shilling, J. E., Pekour, M. S., Fortner, E. C., Artaxo, P., de Sá, S., Hubbe, J. M., Longo, K. M., Machado, L. A. T., Martin, S. T., Springston, S. R., Tomlinson, J., and Wang, J.: Aircraft observations of the chemical composition and aging of aerosol in the Manaus urban plume during GoAmazon 2014/5, Atmos. Chem. Phys., 18, 10773-10797, https://doi.org/10.5194/acp-18-107732018, 2018.

Shrivastava, M. K., Lipsky, E. M., Stanier, C. O., and Robinson, A. L.: Modeling Semivolatile Organic Aerosol Mass Emissions from Combustion Systems, Environ. Sci. Technol., 40, 26712677, https://doi.org/10.1021/es0522231, 2006.

Spracklen, D. V., Jimenez, J. L., Carslaw, K. S., Worsnop, D. R., Evans, M. J., Mann, G. W., Zhang, Q., Canagaratna, M. R., Allan, J., Coe, H., McFiggans, G., Rap, A., and Forster, P.: Aerosol mass spectrometer constraint on the global secondary organic aerosol budget, Atmos. Chem. Phys., 11, 12109-12136, https://doi.org/10.5194/acp-11-12109-2011, 2011.

Toon, O. B., Maring, H., Dibb, J., Ferrare, R., Jacob, D. J., Jensen, E. J., Luo, Z. J., Mace, G. G., Pan, L. L., Pfister, L., Rosenlof, K. H., Redemann, J., Reid, J. S., Singh, H. B., Thompson, A. M., Yokelson, R., Minnis, P., Chen, G., Jucks, K. W., and Pszenny, A.: Planning, implementation, and scientific goals of the Studies of Emissions and Atmospheric Composition, Clouds and Climate Coupling by Regional Surveys (SEAC ${ }^{4} \mathrm{RS}$ ) field mission: Planning SEAC4RS, J. Geophys. Res.-Atmos., 121, 4967-5009, https://doi.org/10.1002/2015JD024297, 2016.

Travis, K. R., Jacob, D. J., Fisher, J. A., Kim, P. S., Marais, E. A., Zhu, L., Yu, K., Miller, C. C., Yantosca, R. M., Sulprizio, M.
P., Thompson, A. M., Wennberg, P. O., Crounse, J. D., St. Clair, J. M., Cohen, R. C., Laughner, J. L., Dibb, J. E., Hall, S. R., Ullmann, K., Wolfe, G. M., Pollack, I. B., Peischl, J., Neuman, J. A., and Zhou, X.: Why do models overestimate surface ozone in the Southeast United States?, Atmos. Chem. Phys., 16, 1356113577, https://doi.org/10.5194/acp-16-13561-2016, 2016.

Tsigaridis, K., Daskalakis, N., Kanakidou, M., Adams, P. J., Artaxo, P., Bahadur, R., Balkanski, Y., Bauer, S. E., Bellouin, N., Benedetti, A., Bergman, T., Berntsen, T. K., Beukes, J. P., Bian, H., Carslaw, K. S., Chin, M., Curci, G., Diehl, T., Easter, R. C., Ghan, S. J., Gong, S. L., Hodzic, A., Hoyle, C. R., Iversen, T., Jathar, S., Jimenez, J. L., Kaiser, J. W., Kirkevåg, A., Koch, D., Kokkola, H., Lee, Y. H., Lin, G., Liu, X., Luo, G., Ma, X., Mann, G. W., Mihalopoulos, N., Morcrette, J.-J., Müller, J.-F., Myhre, G., Myriokefalitakis, S., Ng, N. L., O'Donnell, D., Penner, J. E., Pozzoli, L., Pringle, K. J., Russell, L. M., Schulz, M., Sciare, J., Seland, Ø., Shindell, D. T., Sillman, S., Skeie, R. B., Spracklen, D., Stavrakou, T., Steenrod, S. D., Takemura, T., Tiitta, P., Tilmes, S., Tost, H., van Noije, T., van Zyl, P. G., von Salzen, K., Yu, F., Wang, Z., Wang, Z., Zaveri, R. A., Zhang, H., Zhang, K., Zhang, Q., and Zhang, X.: The AeroCom evaluation and intercomparison of organic aerosol in global models, Atmos. Chem. Phys., 14, 10845-10895, https://doi.org/10.5194/acp-1410845-2014, 2014.

Turquety, S., Logan, J. A., Jacob, D. J., Hudman, R. C., Leung, F. Y., Heald, C. L., Yantosca, R. M., Wu, S., Emmons, L. K., Edwards, D. P., and Sachse, G. W.: Inventory of boreal fire emissions for North America in 2004: Importance of peat burning and pyroconvective injection, J. Geophys. Res.-Atmos., 112, D12S03, https://doi.org/10.1029/2006JD007281, 2007.

van der Werf, G. R., Randerson, J. T., Giglio, L., van Leeuwen, T. T., Chen, Y., Rogers, B. M., Mu, M., van Marle, M. J. E., Morton, D. C., Collatz, G. J., Yokelson, R. J., and Kasibhatla, P. S.: Global fire emissions estimates during 1997-2016, Earth Syst. Sci. Data, 9, 697-720, https://doi.org/10.5194/essd-9-697-2017, 2017.

Volkamer, R., Jimenez, J. L., Martini, F. S., Dzepina, K., Zhang, Q., Salcedo, D., Molina, L. T., Worsnop, D. R., and Molina, M. J.: Secondary organic aerosol formation from anthropogenic air pollution: Rapid and higher than expected, Geophys. Res. Lett., 33, L17811, https://doi.org/10.1029/2006GL026899, 2006.

Warneke, C., Trainer, M., de Gouw, J. A., Parrish, D. D., Fahey, D. W., Ravishankara, A. R., Middlebrook, A. M., Brock, C. A., Roberts, J. M., Brown, S. S., Neuman, J. A., Lerner, B. M., Lack, D., Law, D., Hübler, G., Pollack, I., Sjostedt, S., Ryerson, T. B., Gilman, J. B., Liao, J., Holloway, J., Peischl, J., Nowak, J. B., Aikin, K. C., Min, K.-E., Washenfelder, R. A., Graus, M. G., Richardson, M., Markovic, M. Z., Wagner, N. L., Welti, A., Veres, P. R., Edwards, P., Schwarz, J. P., Gordon, T., Dube, W. P., McKeen, S. A., Brioude, J., Ahmadov, R., Bougiatioti, A., Lin, J. J., Nenes, A., Wolfe, G. M., Hanisco, T. F., Lee, B. H., LopezHilfiker, F. D., Thornton, J. A., Keutsch, F. N., Kaiser, J., Mao, J., and Hatch, C. D.: Instrumentation and measurement strategy for the NOAA SENEX aircraft campaign as part of the Southeast Atmosphere Study 2013, Atmos. Meas. Tech., 9, 3063-3093, https://doi.org/10.5194/amt-9-3063-2016, 2016.

Wesely, M. L.: Parameterization of surface resistances to gaseous dry deposition in regional-scale numerical models, Atmos. Environ., 23, 1293-1304, https://doi.org/10.1016/00046981(89)90153-4, 1989. 
Wofsy, S. C., Afshar, S., Allen, H. M., Apel, E., Asher, E. C., Barletta, B., Bent, J., Bian, H., Biggs, B. C., Blake, D. R., Blake, N., Bourgeois, I., Brock, C. A., Brune, W. H., Budney, J. W., Bui, T. P., Butler, A., Campuzano-Jost, P., Chang, C. S., Chin, M., Commane, R., Correa, G., Crounse, J. D., Cullis, P. D., Daube, B. C., Day, D. A., Dean-Day, J. M., Dibb, J. E., DiGangi, J. P., Diskin, G. S., Dollner, M., Elkins, J. W., Erdesz, F., Fiore, A. M., Flynn, C. M., Froyd, K., Gesler, D. W., Hall, S. R., Hanisco, T. F., Hannun, R. A., Hills, A. J., Hintsa, E. J., Hoffman, A., Hornbrook, R. S., Huey, L. G., Hughes, S., Jimenez, J. L., Johnson, B. J., Katich, J. M., Keeling, R., Kim, M. J., Kupc, A., Lait, L. R., Lamarque, J.-F., Liu, J., McKain, K., Mclaughlin, R. J., Meinardi, S., Miller, D. O., Montzka, S. A., Moore, F. L., Morgan, E. J., Murphy, D. M., Murray, L. T., Nault, B. A., Neuman, J. A., Newman, P. A., Nicely, J. M., Pan, X., Paplawsky, W., Peischl, J., Prather, M. J., Price, D. J., Ray, E., Reeves, J. M., Richardson, M., Rollins, A. W., Rosenlof, K. H., Ryerson, T. B., Scheuer, E., Schill, G. P., Schroder, J. C., Schwarz, J. P., St. Clair, J. M., Steenrod, S. D., Stephens, B. B., Strode, S. A., Sweeney, C., Tanner, D., Teng, A. P., Thames, A. B., Thompson, C. R., Ullmann, K., Veres, P. R., Vieznor, N., Wagner, N. L., Watt, A., Weber, R., Weinzierl, B., Wennberg, P., Williamson, C. J., Wilson, J. C., Wolfe, G. M., Woods, C. T., and Zeng, L. H.: ATom: Merged Atmospheric Chemistry, Trace Gases, and Aerosols, ORNL DAAC, Oak Ridge, Tennessee, USA, https://doi.org/10.3334/ORNLDAAC/1581, 2018.

Xia, A. G., Michelangeli, D. V., and Makar, P. A.: Box model studies of the secondary organic aerosol formation under different $\mathrm{HC} / \mathrm{NO}_{x}$ conditions using the subset of the Master Chemical Mechanism for $\alpha$-pinene oxidation, J. Geophys. Res.-Atmos., 113, D10301, https://doi.org/10.1029/2007JD008726, 2008.

$\mathrm{Xu}$, L., Pye, H. O. T., He, J., Chen, Y., Murphy, B. N., and Ng, N. L.: Experimental and model estimates of the contributions from biogenic monoterpenes and sesquiterpenes to secondary organic aerosol in the southeastern United States, Atmos. Chem. Phys., 18, 12613-12637, https://doi.org/10.5194/acp-18-126132018, 2018.
Zhang, H., Yee, L. D., Lee, B. H., Curtis, M. P., Worton, D. R., Isaacman-VanWertz, G., Offenberg, J. H., Lewandowski, M., Kleindienst, T. E., Beaver, M. R., Holder, A. L., Lonneman, W. A., Docherty, K. S., Jaoui, M., Pye, H. O. T., Hu, W., Day, D. A., Campuzano-Jost, P., Jimenez, J. L., Guo, H., Weber, R. J., Gouw, J. de, Koss, A. R., Edgerton, E. S., Brune, W., Mohr, C., Lopez-Hilfiker, F. D., Lutz, A., Kreisberg, N. M., Spielman, S. R., Hering, S. V., Wilson, K. R., Thornton, J. A., and Goldstein, A. H.: Monoterpenes are the largest source of summertime organic aerosol in the southeastern United States, P. Natl. Acad. Sci. USA, 115, 2038-2043, https://doi.org/10.1073/pnas.1717513115, 2018.

Zhang, L., Gong, S., Padro, J., and Barrie, L.: A size-segregated particle dry deposition scheme for an atmospheric aerosol module, Atmos. Environ., 35, 549-560, https://doi.org/10.1016/S13522310(00)00326-5, 2001.

Zhao, B., Wang, S., Donahue, N. M., Jathar, S. H., Huang, X., Wu, W., Hao, J., and Robinson, A. L.: Quantifying the effect of organic aerosol aging and intermediate-volatility emissions on regional-scale aerosol pollution in China, Sci. Rep., 6, 1-10, https://doi.org/10.1038/srep28815, 2016.

Zhu, L., Val Martin, M., Gatti, L. V., Kahn, R., Hecobian, A., and Fischer, E. V.: Development and implementation of a new biomass burning emissions injection height scheme (BBEIH v1.0) for the GEOS-Chem model (v9-01-01), Geosci. Model Dev., 11, 4103-4116, https://doi.org/10.5194/gmd-114103-2018, 2018. 